\title{
National Weatherization Assistance Program Characterization Describing the Recovery Act Period
}

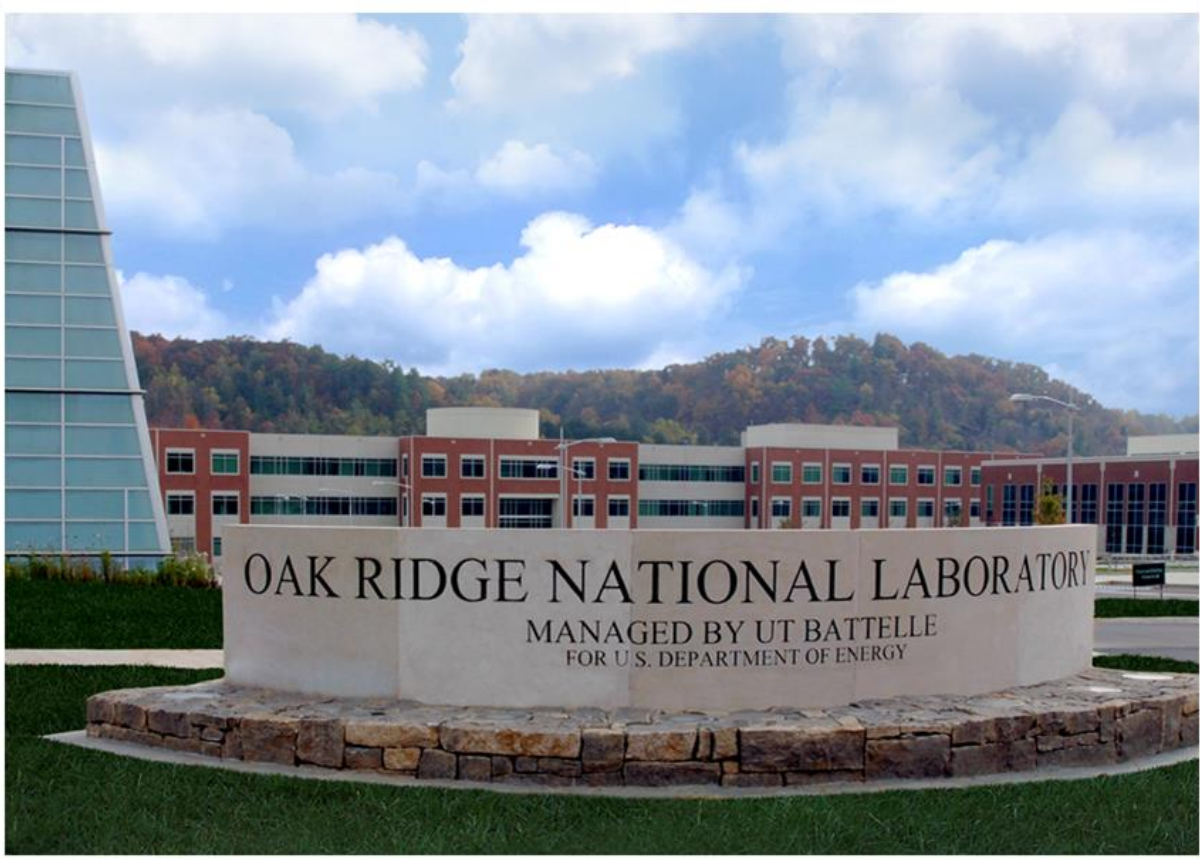

Bruce Tonn

Erin Rose

Beth Hawkins

March 2015 


\section{DOCUMENT AVAILABILITY}

Reports produced after January 1, 1996, are generally available free via US Department of Energy (DOE) SciTech Connect.

Website http://www.osti.gov/scitech/

Reports produced before January 1, 1996, may be purchased by members of the public from the following source:

National Technical Information Service

5285 Port Royal Road

Springfield, VA 22161

Telephone 703-605-6000 (1-800-553-6847)

TDD 703-487-4639

Fax 703-605-6900

E-mail info@ntis.gov

Website http://www.ntis.gov/help/ordermethods.aspx

Reports are available to DOE employees, DOE contractors, Energy Technology Data Exchange representatives, and International Nuclear Information System representatives from the following source:

Office of Scientific and Technical Information

PO Box 62

Oak Ridge, TN 37831

Telephone 865-576-8401

Fax 865-576-5728

E-mail reports@osti.gov

Website http://www.osti.gov/contact.html

This report was prepared as an account of work sponsored by an agency of the United States Government. Neither the United States Government nor any agency thereof, nor any of their employees, makes any warranty, express or implied, or assumes any legal liability or responsibility for the accuracy, completeness, or usefulness of any information, apparatus, product, or process disclosed, or represents that its use would not infringe privately owned rights. Reference herein to any specific commercial product, process, or service by trade name, trademark, manufacturer, or otherwise, does not necessarily constitute or imply its endorsement, recommendation, or favoring by the United States Government or any agency thereof. The views and opinions of authors expressed herein do not necessarily state or reflect those of the United States Government or any agency thereof. 


\title{
National Weatherization Assistance Program Characterization Describing the Recovery Act Period
}

\author{
Bruce Tonn, ORNL \\ Erin Rose, ORNL \\ Beth Hawkins, ORNL
}

March 2015

\author{
Prepared by \\ OAK RIDGE NATIONAL LABORATORY \\ Oak Ridge, Tennessee 37831-6283 \\ managed by \\ UT-BATTELLE, LLC \\ for the \\ US DEPARTMENT OF ENERGY \\ under contract DE-AC05-00OR22725
}





\section{CONTENTS}

\begin{tabular}{|c|c|}
\hline \multicolumn{2}{|r|}{ IST OF FIGURES } \\
\hline \multirow{2}{*}{\multicolumn{2}{|c|}{ LIST OF TABLES }} \\
\hline & \\
\hline \multicolumn{2}{|r|}{ ACKNOWLEDGEMENTS } \\
\hline \multicolumn{2}{|r|}{ 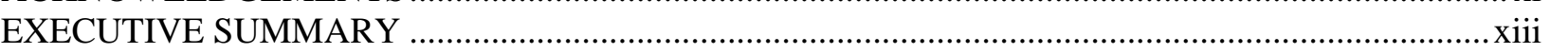 } \\
\hline \multicolumn{2}{|c|}{ 1. INTRODUCTION.. } \\
\hline \\
\hline 2.1 & FUNDING, JOBS, AND PRODUCTION. \\
\hline 2.2 & ALLENGES DURING THE RECOVERY ACT ........ 7 \\
\hline 2.3 & DAVIS-BACON: UNINTENDED CONSEQUENCES.... \\
\hline 2.4 & OTHER FEEDBACK FROM THE RECOVERY ACT PERIOD . \\
\hline 2.5 & LEVERAGED FUNDING DURING THE RECOVERY ACT PERIOD.. \\
\hline 2.6 & SUMMARY... \\
\hline \\
\hline 3.1 & DEM \\
\hline 3.2 & AUDIT APPROACHES AND DIAGNOSTIC PROCEDURES USED .... \\
\hline 3.3 & MEASURES INSTALLED . \\
\hline 3.4 & CLIENT EDUCATION. \\
\hline 3.5 & TRAINING . \\
\hline 3.6 & LARGE MULTIFAMILY B \\
\hline 3.7 & OTHER MISCELLANEOUS TOPICS . \\
\hline \multicolumn{2}{|r|}{ 4. CONCLUSIONS } \\
\hline \multicolumn{2}{|r|}{ REFERENCES } \\
\hline \multicolumn{2}{|c|}{ APPENDIX - RESEARCH APPROACH . } \\
\hline A.1 & SURVEY INSTRUMENTS AND DAT \\
\hline A. 2 & SAMPLING FRAME AND DATA.... \\
\hline A.3 & UURVY IMPLEMENTATION DETAILS . \\
\hline & DATA LIMITATIONS. \\
\hline
\end{tabular}





\section{LIST OF FIGURES}

Figure $\quad$ Page

Figure 2.1 DOE WAP Expenditures during the Recovery Act Period ................................................ 4

Figure 2.2 Weatherization Employment Supported by Recovery Act Funds ......................................... 4

Figure 2.3 Units Weatherized Using ARRA and Normal Appropriations (Formula) Funding ................... 5

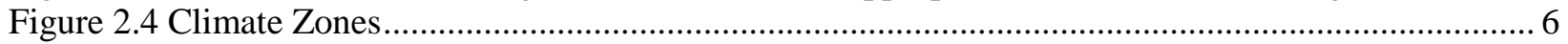

Figure 2.5 Impacts of ARRA Period: Local Agency Staff Experience …............................................. 14

Figure 2.6: Clusters of Subgrantees Based on Spent DOE \& Leveraged Funds .................................... 17

Figure 2.7 Leveraging Changes During and Post-ARRA by Leveraging Source ...................................... 21 



\section{LIST OF TABLES}

Table

Page

Table 2.1 Weatherized Units in Program Years 2008 and 2010 5

Table 2.3 Recovery Act Changed Milieu Surrounding Weatherization Programs (\%) .............................. 9

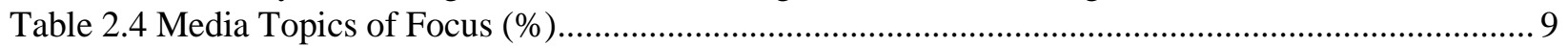

Table 2.5 Focus of Media Attention on Subgrantee Programs During the Recovery Act (\%) ................... 10

(1= yes, 0 -no).

Table 2.6 Media Coverage of Subgrantee Weatherization Programs During the Recovery Act............... 10

Table 2.7: Factors Influencing Program Costs During Recovery Act Period (\%) .................................... 10

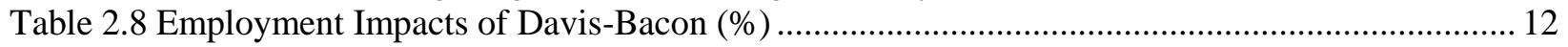

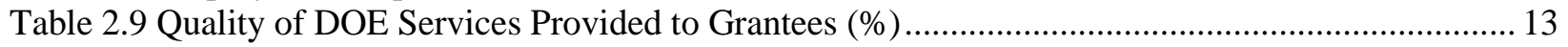

Table 2.10 Quality of Grantee Services Provided to Subgrantees (\%) ...................................................... 14

Table 2.11 DOE Guidance to Subgrantees During ARRA Period (\%) .................................................... 14

Table 2.12 DOE and Leveraged Weatherization Funding in PY 2010 and PY 2008 (\$ millions) ............. 16

Table 2.13 Clusters of Subgrantee Weatherization Funding by Climate Zone......................................... 17

Table 2.14 Grantees and Subgrantees: Importance of Leveraged Grants (\%) ......................................... 17

Table 2.15 Leveraging Sources and History by Grantee and Subgrantees PY 2010 .............................. 19

Table 2.16 Grantees and Subgrantees: Success at Acquiring Leveraged Funds (\%)............................... 20

Table 2.17 Grantees and Subgrantees: Impact of ARRA on existing leveraging (\%) ............................... 20

Table 2.18 LIHEAP Related Results from PY 2010 Surveys of Grantees and Subgrantees:

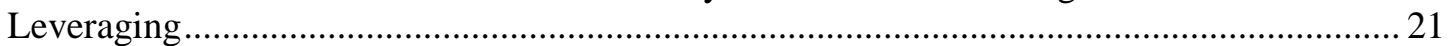

Table 3.1 PY 2010 Clients Household Characteristics by Building Unit Type ........................................2 24

Table 3.2 PY 2010 Clients in Single Family Homes Household Characteristics by Climate Zone ........... 25

Table 3.3 PY 2010 Clients Housing Unit Characteristics by Building Type ............................................26

Table 3.4 PY 2010 Single Family Housing Unit Characteristics by Climate Zone ................................... 27

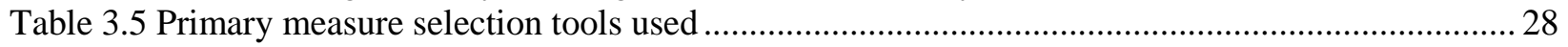

Table 3.6 Most commonly used calculation procedures ................................................................... 28

Table 3.7 Diagnostic procedures performed by subgrantees in Program Year 2010 and 2008 ................ 29

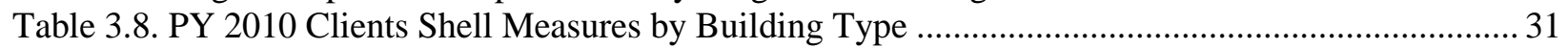

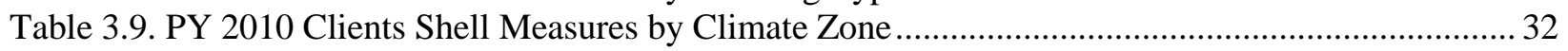

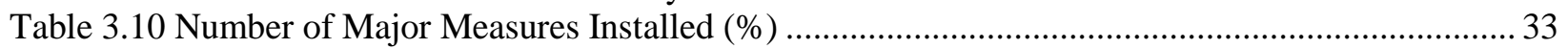

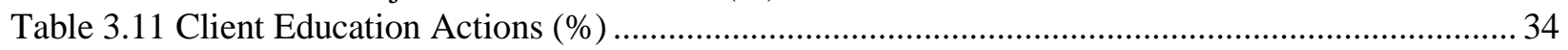

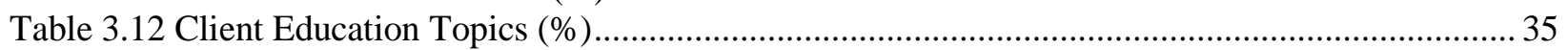

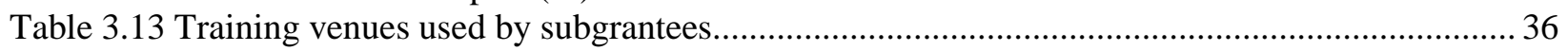

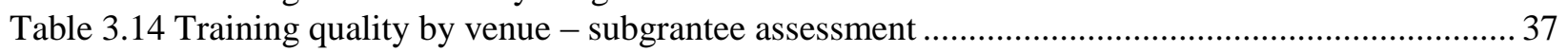

Table 3.15 Barriers to Weatherizing Large Multifamily Buildings (\%) ................................................... 38

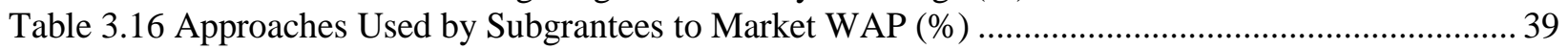

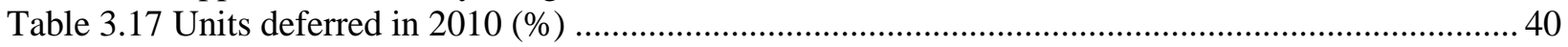

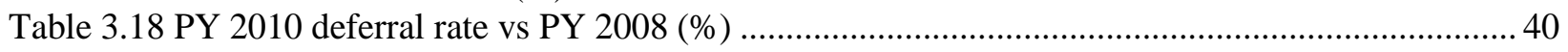

Table 3.19 Previously deferred units slated to be weatherized PY $2010(\%)$........................................... 41 



\section{ACRONYMS}

AC

ARRA

CAA

CFL

CFM

CFR

$\mathrm{CO}$

CY

DOE

DoL

EA-QUIP

ECM

EISA

HHS

HUD

HVAC

LIHEAP

LMF

MH

MHEA

NASCSP

NEAT

OMB

OWIP

PAGE

PPS

PVE

PY

RPS

SERC

SF

SHPO

SIR

SMF

STD

TREAT

WAP

Wx
Air Conditioning

American Recovery and Reinvestment Act

Community Action Agency

Compact Florescent Light

Cubic Feet per Minute

Code of Federal Regulations

Carbon Monoxide

Calendar Year

Department of Energy

Department of Labor

Energy Audit using the Queens Information Package

Energy Conservation Measure

Energy Independence Security Act

Depart of Health and Human Services

Housing and Urban Development

Heating, Ventilation, and Air Conditioning

Low Income Home Energy Assistance Program

Large Multifamily

Mobile Home

Manufactured Home Energy Audit

National Association for State Community Service Providers

National Energy Audit Tool

Office of Management and Budget

Office of Weatherization and Intergovernmental Programs

Performance and Accountability for Grants in Energy

Probability Proportional Sampling

Petroleum Violation Escrow

Program Year

Renewable Portfolio Standards

Sustainable Energy Resources for Consumers

Single Family

State Historic Preservation Office

Savings-to-Investment Ratio

Small Multifamily

Standard Deviation

Targeted Retrofit Energy Analysis Tool

Weatherization Assistance Program

Weatherization 



\section{ACKNOWLEDGEMENTS}

The work presented in this report was funded by the U.S. Department of Energy's (DOE) Office of Weatherization and Intergovernmental Programs (OWIP).

We wish to thank all of the Grantees and Subgrantees who responded to our survey requests. We also wish to thank Claire Cowan and her staff at the Energy Center of Wisconsin for leading the data collection efforts and to David Carroll and his staff at APPRISE, Inc. for preparing the databases. We wish to thank Kelly Cutchin for her comments on a draft of this report. 



\section{EXECUTIVE SUMMARY}

This report provides a characterization of the U.S. Department of Energy's (DOE) Weatherization Assistance Program (WAP) specifically for Program Year (PY) 2010 and more generally with respect to its administration during the American Recovery and Reinvestment Act (ARRA) period. Briefly, WAP provides grants, guidance, and other support to Grantees: weatherization programs administered by each of the 50 states, the District of Columbia, territories and several Native American tribes. The Grantees, in turn, oversee a network of 900+ local weatherization agencies (Subgrantees): Community Action Agencies (CAAs), nonprofit organizations, and local government agencies that are eligible to receive weatherization funding from DOE. These weatherization agencies qualify eligible households, assess their homes' energy efficiency opportunities, install energy-saving measures, and inspect the work. The work performed includes air sealing, insulation upgrades, furnace replacements, and other dwellingspecific measures found to be cost-effective, as well as home improvements provided to ensure the health and safety of household occupants. The work is done at no cost to the eligible participants.

In April 2009, the U.S. Congress passed ARRA (also referred to herein as the Recovery Act). Included in the hundreds of billions of dollars of programs, initiatives, and investments was $\$ 5$ billion for WAP. The national weatherization network was allotted approximately three years to spend these funds. Annually, this funding represents about six times more per year than Congress had been typically appropriating for WAP. The huge increase in funding was based on the assumption that weatherization was a 'shovel ready' program, capable of quickly ramping up production and, most importantly, employing significant numbers of individuals to weatherize income-qualifying homes.

The Recovery Act also included some additional provisions specifically related to WAP:

- The income eligibility threshold for the program was raised from $150 \%$ of the Federal Poverty Level to 200\%;

- The average DOE funding that could be spent per weatherized unit was raised from $\$ 2500$ to $\$ 6500$; and

- WAP Grantees and Subgrantees had to adhere to the provisions of the Davis-Bacon Act with respect to prevailing wages and paperwork reporting.

The national weatherization network increased its workforce to meet weatherization production goals set by DOE. In PY 2010, the network weatherized 332,000 units, up from 98,000 units in PY 2008. The number of weatherization jobs directly supported by Recovery Act funds peaked at just under 16,000 in the fourth quarter of calendar year (CY) 2010. By the end of the WAP ARRA period, the DOE program had met its target, weatherizing over 1 million homes across the United States and its eligible territories.

WAP as implemented during ARRA was comparable to the program pre-ARRA. For example, comparing results of surveys administered to Grantees and Subgrantees characterizing PY 2008 to survey results related to PY $2010^{1}$, program aspects were similar in the following categories:

- Frequency in use of various diagnostic procedures (e.g., blower door tests)

- Approaches to and topics for client education (e.g., most client education was delivered during the in-home audit and the most popular topics were thermostats, insulation and lighting)

- Approaches for measure selection (e.g., priority lists versus computerized audits)

- Measures installed (e.g., air sealing measures were the most frequently installed in both PYs)

\footnotetext{
${ }^{1} 97 \%$ of Grantees completed a web-based survey about their programs in PY 2010. Two surveys were administered to Subgrantees: $92 \%$ completed the survey with general program questions and $84 \%$ completed a survey that had more in-depth questions.
} 
- Use of various training venues (e.g., National Weatherization Program Conference, regional weatherization conferences)

- Weatherization program marketing at the local level (e.g., mailings to clients, radio ads)

The substantial funding increase had numerous impacts on the national weatherization network. Surveys completed by the Grantees and Subgrantees indicated that because of ARRA:

- The political visibility of their programs increased significantly

- Organizational responsibilities were shifted

- New laws, rules and regulations were enacted

- Media attention of their programs increased

- Federal oversight of their programs increased

The additional oversight increased administrative costs. Also increasing costs was the provision in the Recovery Act that WAP fall under the provisions of the Davis-Bacon Act of 1931. This Act requires that all federal construction and public works projects need to pay 'prevailing wages' for laborers and mechanics. Production ramp-up delayed almost six months while the U.S. Department of Labor determined what the prevailing wages would be county-by-county for weatherization-related jobs. Administrative costs were increased because of weekly time keeping paperwork requirements. Job costs were increased because in many instances the prevailing wages were higher than wages previously paid by the Subgrantees. Overall, $94 \%$ of Grantees and $80 \%$ of Subgrantees reported that Davis-Bacon increased their costs.

The influx of ARRA funds changed how the program operated at the margin. For example, Subgrantees were able to purchase new diagnostic tools, which led to small increases in the use of infrared scanners to examine insulation levels. Two-thirds of Subgrantees observed some economies of scale as their programs increased. It should also be mentioned that because of the increased number of new workers, the overall level of experience of the weatherization workforce decreased. Additionally, the rate that homes were deferred for weatherization increased somewhat. ${ }^{2}$

The demographic and housing characteristics of the WAP recipients in PY 2010 differed somewhat from the PY 2008 recipients. For example, the households and homes weatherized in PY 2010 meet the following descriptors:

- $\quad$ Higher household incomes - e.g., average annual household income for families living in single family (SF) homes in PY 2010 was $\$ 15,700$ versus \$13, 200 in PY 2008 and for mobile homes (MH) was $\$ 13,400$ in PY 2010 versus $\$ 11,470$ in PY 2008.

- $\quad$ Fewer households contain high-priority individuals - e.g., the percent of SF homes with a person with disabilities was 30\% in PY 2010 versus 39\% in PY 2008 and for MH was 39\% versus 49\%.

- $\quad$ More likely to be non-white compared to other PYs - The percentage of Black and Hispanic households living in SF and MH served increased (e.g., from 31\% in PY 2008 to 39\% in PY 2010 for SF homes and $15 \%$ to $22 \%$ for $\mathrm{MH}$ ).

- $\quad$ Smaller in size, on average - e.g., the average size of small multifamily (SMF) unit in PY 2010 was $800 \mathrm{ft}^{2}$ versus $1,054 \mathrm{ft}^{2}$ in PY 2008

- $\quad$ Newer vintage - e.g., the percent of SF, SMF and large multifamily (LMF) built 1970 or later increased from $26 \%$ to $33 \%, 35 \%$ to $82 \%$ and $49 \%$ to $79 \%$, respectively, from PY 2008 to PY 2010.

\footnotetext{
${ }^{2}$ See Rose, E. et al. (2014) Exploratory Review of State, Agency and Client Experiences with Deferred Services Under the Weatherization Assistance Program.
} 
- $\quad$ Less likely to use bulk fuels - the percent of weatherized SF, MF, SMF and LMF using fuel oil dropped from $14 \%$ to $5 \%, 10 \%$ to $5 \%, 10 \%$ to $3 \%$, and $17 \%$ to $4 \%$, respectively from PY 2008 to PY 2010.

- $\quad$ More likely to use supplemental fuels - e.g., 15\% of SF homes used electricity for supplemental heat in PY 2010 versus 9\% in PY 2008.

DOE allows the Grantees and Subgrantees to use WAP funding to leverage additional funding for lowincome weatherization. For example, in PY 2008, DOE provided \$236 million in funding that was leveraged to obtain over $\$ 600$ million in additional funding. In PY 2010, DOE funding was $\$ 2$ billion and leveraged funding was just over $\$ 700$ million. The percent of DOE funds invested in DOE units increased from $49 \%$ to $86 \%$.

Concern was expressed within the national weatherization network that the influx of ARRA funds would permanently damage leveraging relationships. Both Grantees and Subgrantees reported that some leveraged relationships were indeed damaged, a few permanently. This is an important issue because in many instances over a decade of effort was invested to secure the leveraging relationships. However, twothirds of Grantees and over $40 \%$ of Subgrantees stated that they believe that the long-term impacts of ARRA on leveraging relationships will be positive, versus only $12 \%$ and $14 \%$ of Grantees and Subgrantees, respectively, believing otherwise.

Despite reported stresses involved with the Recovery Act including negative media coverage, $44 \%$ of Grantees thought that the added attention to weatherization during the Recovery Act was beneficial; only $12 \%$ disagreed. Amongst Subgrantees, 51\% thought the attention was beneficial, and only $7 \%$ disagreed. Almost half of the Subgrantees thought the public's support for weatherization increased; only 3\% thought that support decreased. These beliefs undoubtedly underlie the mostly positive outlook that the respondents have with respect to the future of their leveraged funding.

The national weatherization network reported challenges still to overcome. For example, the Subgrantees were asked about the public's understanding of weatherization. A majority have some concerns: $57 \%$ reported that the public's understanding of their programs is only fair to poor, with only $43 \%$ reporting good to excellent.

Other than the sheer number of units weatherized during PY 2010, the program as administered in PY 2010 appears to have been similar to the program administered in PY 2008. Overall, there were no substantive changes in audit tools used, measures installed, training offered and taken, and client education practices. The characteristics of the recipients and their homes changed somewhat, due to a combination of an increase in the income eligibility threshold (from 150\% to 200\% of poverty) and a larger percentage of weatherized homes falling into the hot climate regions.

In summary, the Recovery Act was a unique period in the history of WAP. Funding reached unprecedented levels. The media attention on and oversight of WAP was also unprecedented. The national network ramped-up its workforce and met its production goals. Survey results suggest that the Grantees' experiences of the Recovery Act were more negative than the experiences of the Subgrantees, but overall, the network seems to have judged that the Recovery Act was, on balance, positive for lowincome weatherization in the United States. 



\section{INTRODUCTION}

This report is part of the Recovery Act period national evaluation of the U.S. Department of Energy's (DOE) Weatherization Assistance Program (WAP). The evaluation is being managed by Oak Ridge National Laboratory (ORNL) on behalf of the U.S. Department of Energy (DOE). The pages that follow describe the nationwide WAP network and weatherization activities during the Recovery Act generally and Program Year (PY) 2010, more specifically.

WAP was created by Congress in 1976 under Title IV of the Energy Conservation and Production Act. The purpose and scope of the Program as currently stated in the Code of Federal Regulations (CFR) 10 CFR 440.1 is "to increase the energy efficiency of dwellings owned or occupied by low-income persons, reduce their total residential energy expenditures, and improve their health and safety, especially lowincome persons who are particularly vulnerable such as the elderly, persons with disabilities, families with children, high residential energy users, and households with high energy burden." (Code of Federal Regulations, 2011)

WAP provides grants, guidance, and other support to Grantees: weatherization programs administered by each of the 50 states, the District of Columbia, territories and several Native American tribes. The Grantees, in turn, oversee a network of 900+ local weatherization agencies (Subgrantees): Community Action Agencies (CAAs), nonprofit organizations, and local government agencies that are eligible to receive weatherization funding from DOE. These weatherization agencies qualify eligible households, assess their homes' energy efficiency opportunities, install energy-saving measures, and inspect the work. The work performed includes air sealing, insulation upgrades, furnace replacements, and other dwellingspecific measures found to be cost-effective, as well as home improvements needed to ensure the health and safety of household occupants. The work is done at no cost to the eligible participants.

It should be noted that in March 2009, a Final Rule was published in the Federal Register amending DOE's definition of "state" to include the Commonwealth of Puerto Rico, Guam, the US Virgin Islands, the Commonwealth of the Northern Marianas Islands, and American Samoa. The new definition is consistent with modifications made to Section 411(c) of the Energy Independence and Security Act (EISA) of 2007. The final rule extended all federal regulations and guidance of the Weatherization Assistance Program (WAP) to these U.S. territories under both regular and ARRA program years. Therefore, this report's characterization of WAP during the ARRA period includes the newly developed US territory programs that were not included in the characterization report describing the pre-ARRA period.

In April 2009, the U.S. Congress passed the America Recovery and Reinvestment Act (ARRA, also referred to herein as the Recovery Act). Included in the hundreds of billions of dollars of programs, initiatives, and investments was $\$ 5$ billion for WAP. The national weatherization network was given approximately three years to spend these funds. Annually, this funding represents about six times more per year than Congress had been typically appropriating for WAP. The huge increase in funding was based on the assumption that weatherization was a 'shovel ready' program, capable of quickly ramping up production and, most importantly given a major goal of ARRA, employing significant numbers of individuals to weatherize low-income homes.

The Recovery Act also included some additional provisions specifically related to WAP:

- The income eligibility threshold for the program was raised from $150 \%$ of the Federal Poverty Level to 200\%; 
- The average DOE funding that could be spent per weatherized unit was raised from $\$ 2500$ to $\$ 6500$; and

- WAP Grantees and Subgrantees had to adhere to the provisions of the Davis-Bacon Act with respect to prevailing wages and paperwork reporting.

ARRA funding for WAP significantly impacted Program operation and management. Numerous important process evaluation issues were identified by evaluation team and the national weatherization community. These are mostly addressed in Section 2. The next section documents program operations, such as the use of diagnostic tools and audit approaches. Where useful, comparisons are made to how WAP operated in the year just before the Recovery Act, PY 2008. Appendix A presents the research designs and data collection approaches used to generate the results presented in the report as well as on sample sizes and response rates. 


\section{THE RECOVERY ACT MILIEU}

\subsection{FUNDING, JOBS, AND PRODUCTION}

During his first term, President Obama signed ARRA into law in response to the worst economic crisis in the US since the Great Depression. In particular, the Recovery Act targeted 'shovel ready' project (i.e., could ramp-up quickly to support job creation) opportunities to increase employment. Alongside major critical infrastructure projects, the Obama Administration took the opportunity to further its clean energy agenda. The clean energy package in the Recovery Act had four components: efficiency, the Grid, transportation, and clean energy manufacturing and other related projects. ${ }^{3}$ Weatherization was identified as a program that was both shovel ready and capable of meeting energy efficiency goals. President Obama emphasized the relevance of WAP as providing three major benefits; (1) job creation by increasing the workforce needed to manufacture and sell weatherization materials, to deliver the weatherization service, and to manage its administration; (2) energy conservation and security; and (3) relief for households burdened with higher than necessary home-energy costs. Given this, the decision was made to allocate $\$ 5$ billion of Recovery Act funds to DOE's Weatherization Assistance Program.

Figures 2.1 to 2.3 depict impacts that the Recovery Act had on WAP. ${ }^{4}$ Figure 2.1 tracks DOE WAP expenditures from the beginning of the Recovery Act in April 2009 to when the funds were almost completely exhausted in late 2013. Expenditures peaked at over $\$ 500$ million per quarter in Calendar Year (CY) Q1 2011. Weatherization employment supported by ARRA peaked a quarter before that at over 15,000 jobs (see Figure 2.2). Figure 2.3 shows units weatherized peaked in CY Q4 2011 at almost 90,000 units. In comparison, for the entire 2008 Program Year DOE funds supported the weatherization of just under 100,000 units. It should be noted that during the Recovery Act, WAP continued to receive normal program appropriations from Congress. Jobs weatherized utilizing these funds are labeled 'formula units weatherized' in Figure 2.3. Plotting both formula and ARRA period units weatherized indicates how much production ramped-up during the ARRA period. Additionally, the plots indicate that formula units weatherized as of CY Q1 2014 were substantially below formula units weatherized preARRA. ${ }^{5}$

Lastly, Table 2.1 presents units weatherized by housing type for the year before the Recovery Act (PY 2008) and for one year during the Recovery Act (PY 2010). The national program's character, that of focusing predominately on single family, small multi-family, and mobile homes, did not change appreciably during the Recovery Act, though the share of weatherized units being in large multifamily buildings increased somewhat. However, Table 2.2 indicates that the share of units weatherized in the hot/humid and hot/dry regions of the U.S. did increase appreciably during ARRA (Figure 2.4 presents the climate zone designations used in this study).

\footnotetext{
${ }^{3}$ Aldy, J. 2011. A Preliminary Review of the American Recovery Act's Clean Energy Package. RWP11-048, Kennedy School of Government, Harvard University, Cambridge, MA, December.

${ }_{5}^{4}$ Data presented in these figures was drawn from DOE's Performance and Accountability for Grants in Energy system.

${ }^{5}$ This lack of production is due to sharp reductions in Congressional appropriations for WAP. This has left many Grantees and Subgrantees scrambling to keep their programs in operation. As an example is testimony to the Vermont Senate and Welfare Committee by the state's weatherization program for funding to prevent the mothballing of weatherization equipment purchased during the Recovery Act period and to keep weatherization waiting lists from exceeding a year. Shollenberger, A. 2014 http://www2.leg.state.vt.us/CommitteeDocs/2014/Senate\%20Health\%20and\%20Welfare/Budget\%20Discussion/W Amy\%20Sh ollenberger Weatherization\%20Assistance\%20Program\%20Written\%20Testimony 4-16-2014.pdf
} 


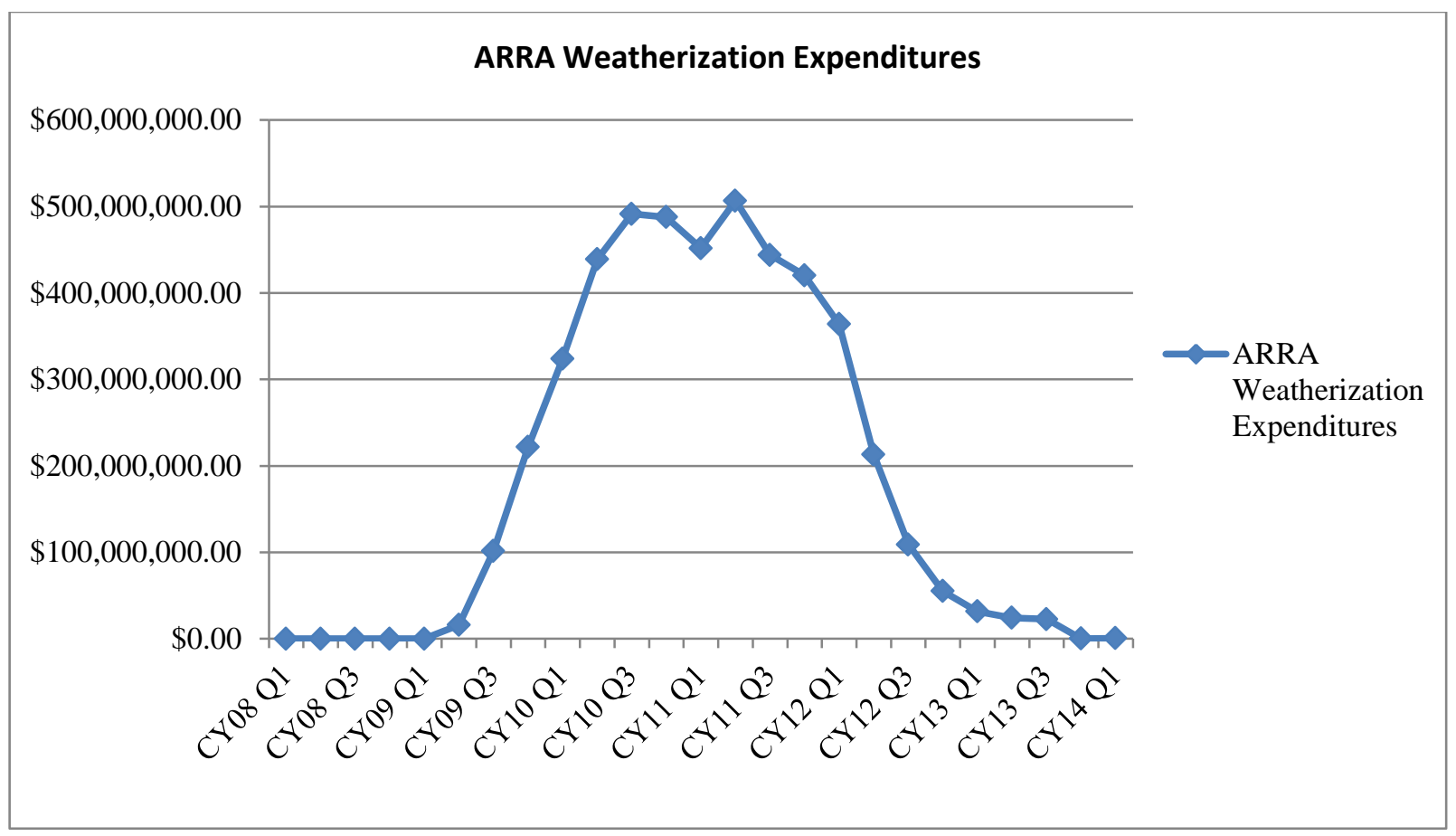

Figure 2.1 DOE WAP Expenditures during the Recovery Act Period

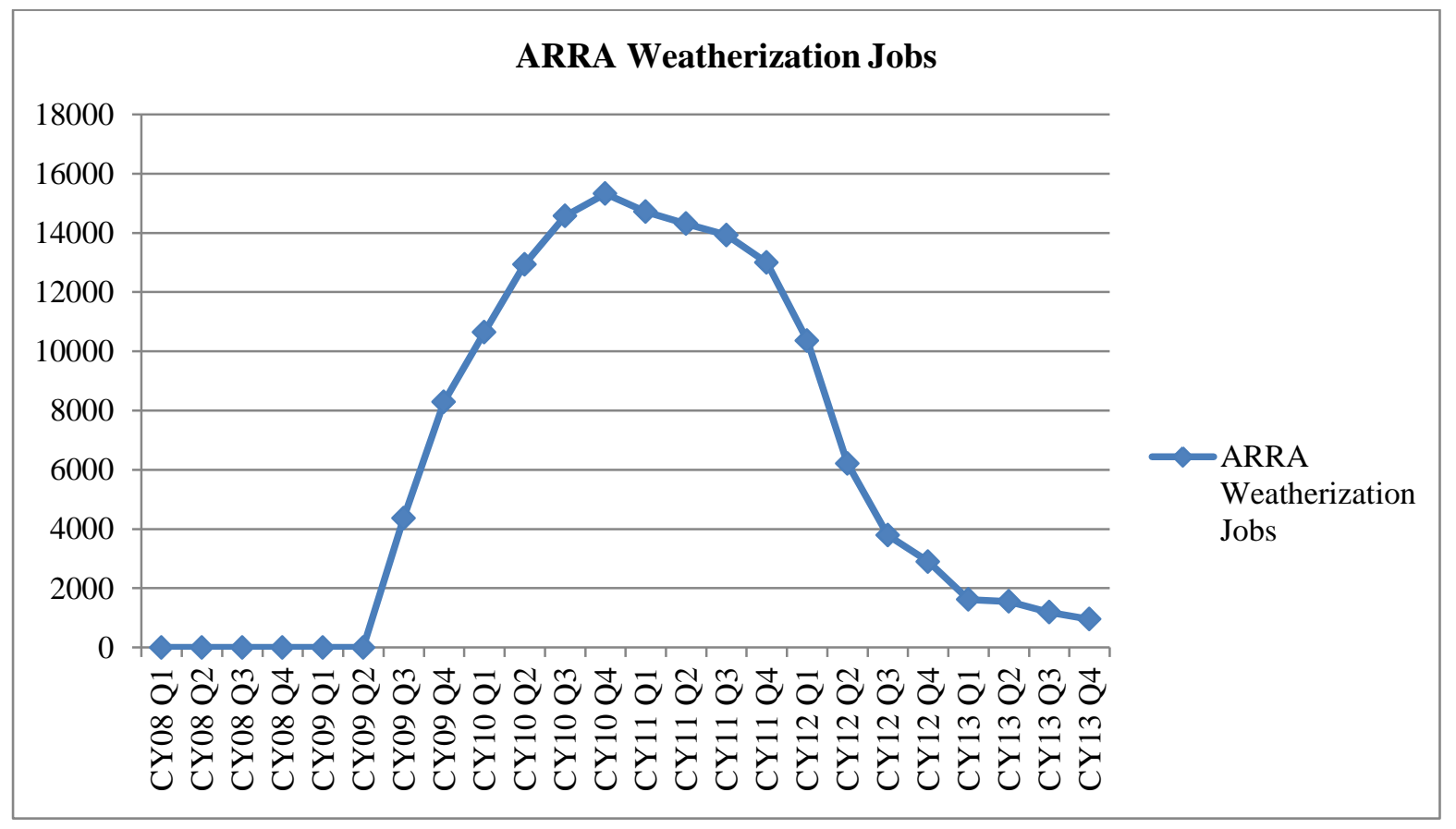

Figure 2.2 Weatherization Employment Supported by Recovery Act Funds 


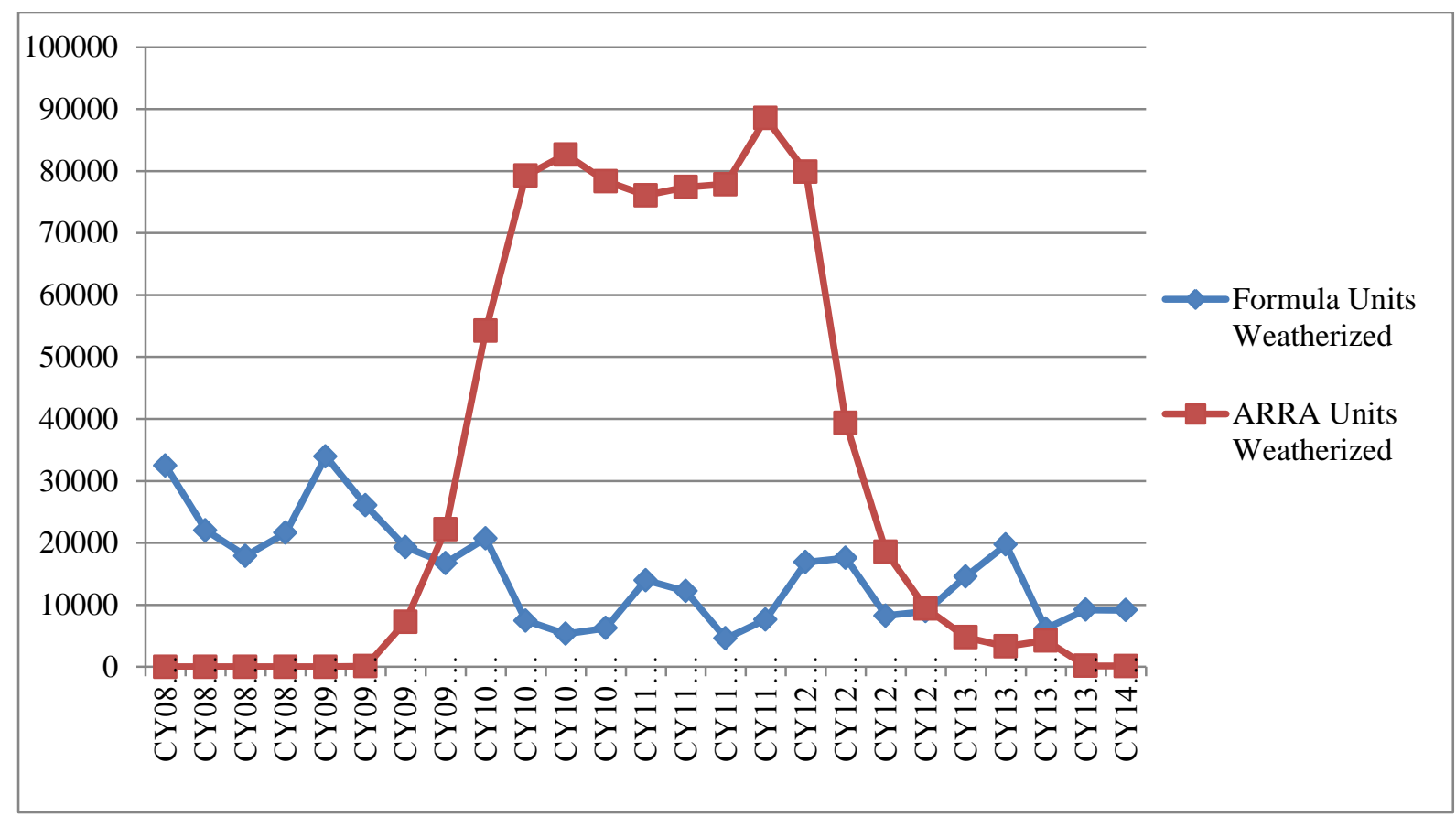

Figure 2.3 Units Weatherized Using ARRA and Normal Appropriations (Formula) Funding

Table 2.1 Weatherized Units in Program Years 2008 and 2010

\begin{tabular}{|l|c|c|c|c|}
\hline Housing Type & 2008 & 2008 by $\%$ & 2010 & 2010 by \% \\
\hline Site Built (1-4) Units & 62,835 & $64 \%$ & 215,445 & $65 \%$ \\
\hline Mobile Homes & 17,754 & $18 \%$ & 48,267 & $14.5 \%$ \\
\hline Large Multi-family Units (5+) & 17,376 & $18 \%$ & $68,153^{6}$ & $20.5 \%$ \\
\hline Total & $\mathbf{9 7 , 9 6 5}$ & $\mathbf{1 0 0 \%}$ & $\mathbf{3 3 1 , 8 6 5}$ & $\mathbf{1 0 0 \%}$ \\
\hline
\end{tabular}

Table 2.2 Weatherized Units in Program Years 2008 and 2010 by Climate Zone

\begin{tabular}{|l|c|c|c|c|}
\hline & 2008 Units & $2008 \%$ & 2010 Units & $2010 \%$ \\
\hline Very Cold & 24749 & $25 \%$ & 58584 & $18 \%$ \\
\hline Cold & 42233 & $43 \%$ & 127386 & $38 \%$ \\
\hline Moderate & 18794 & $19 \%$ & 56006 & $17 \%$ \\
\hline Hot/Humid & 6390 & $7 \%$ & 55157 & $17 \%$ \\
\hline Hot/Dry & 5799 & $6 \%$ & 34732 & $10 \%$ \\
\hline Total & $\mathbf{9 7 , 9 6 5}$ & $\mathbf{1 0 0 \%}$ & $\mathbf{3 3 1 , 8 6 5}$ & $\mathbf{1 0 0 \%}$ \\
\hline
\end{tabular}

\footnotetext{
${ }^{6}$ This number excludes weatherized large multifamily units about which nothing is known and also weatherized
} shelters. For completeness, the total number of weatherized large multifamily units is 73,240. 


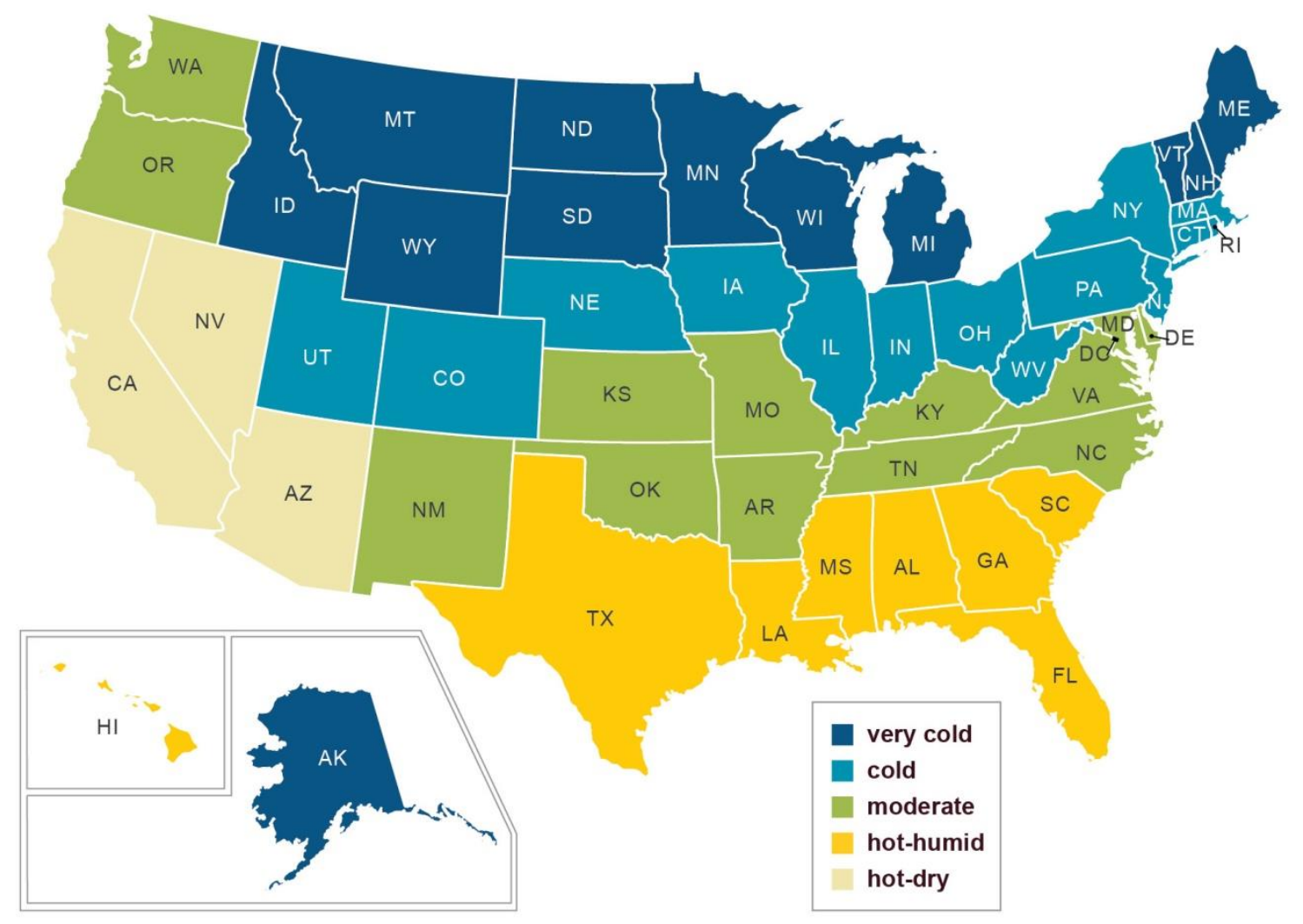

Figure 2.4 Climate Zones 


\subsection{WEATHERIZATION NETWORK CHALLENGES DURING THE RECOVERY ACT}

The survey results presented in this section suggest that the experiences of the Grantees and Subgrantees differed substantially during the Recovery Act period. For example, a solid majority of Subgrantees reported significant changes in their weatherization network $(63 \%)$ whereas only one-third of the Grantees reported significant changes (Table 2.3). This result is not unexpected since the bulk of new hires and new contracting for weatherization happened at the local level. Grantees that reported significant changes were those who had small programs pre-ARRA (e.g., in hot climate states, see Figure 2.4) or territories like Puerto Rico that did not have a weatherization program pre-ARRA. It should also be noted that $35 \%$ of Grantees reported adding new Subgrantees to their stable of local weatherization providers during the ARRA period.

The huge funding increase did indeed draw the attention of state legislators and bureaucrats. Over $60 \%$ of Subgrantees indicated that the visibility of their programs to elected officials increased during the Recovery Act period. Almost one-half of the Grantees and Subgrantees alike reported that organizational responsibilities for overseeing their programs changed during the Recovery Act. Almost a third of the Grantees reported that new laws and regulations were passed that impacted their programs, with a substantial majority of Grantees believing that ARRA was the cause of these changes. These changes, in turn, impacted one-half of the Subgrantees. Forty-four percent of the Grantees felt that these new laws and regulations were not beneficial to their programs versus $31 \%$ that felt they were beneficial.

Because of the multiple changes observed across the WAP it is plausible to suggest that the national weatherization network was under stress. Not only did it ramp up production substantially, but it increased the ranks of its workers and were required to follow new management arrangements, laws and regulations targeted at their programs. This stress on the organizational culture of the network is reflected in the survey responses to questions assessing the Grantee-Subgrantee relationships indicating an increase in negative relationship between the two (Table 2.3),

The manner in which the media portrayed low-income weatherization during the ARRA period depended on the locus of the attention. As shown in Table 2.3, Grantees felt that media attention was more negative than did the Subgrantees. Not unexpectedly, a higher percentage of Grantees also believed that the quality of the media attention was not very high, though the media did not receive overwhelming approval from the Subgrantees either. Table 2.4 provides some insights into the Grantees dissatisfaction with media attention, as the media focused much more on waste, fraud and abuse and on organizational mis-steps at the state level than on the local level. Fewer Grantees than Subgrantees reported that the media focused on the positive aspects of weatherization, such as energy saved, jobs created, and the household benefits of WAP.

There are some patterns to the positive and negative media attention. The results presented in Tables 2.5 and 2.6 suggest that Subgrantee programs' in the very cold and cold regions enjoyed more positive media attention than programs located within hot humid and hot dry regions of the U.S. One factor at play here is that programs in the hot regions did indeed receive a higher proportion of federal weatherization funding under ARRA than before ARRA due to a provision in the law that changes the funding formula to the advantage of such regions when funding exceeds a threshold of $\$ 275 \mathrm{M}$ per year. Thus, those Grantees and Subgrantees in the hot humid and hot dry states had a relatively higher hill to climb with respect to ramping up their weatherization programs which may have contributed to some of the negative attention towards the beginning of the ARRA period. Overall, 52\% of Subgrantees reported that the media attention would have no long-term impact on funding, $21 \%$ felt the attention would have a negative impact, and $27 \%$ felt the attention would lead to an increase in funding for weatherization. 
In a recent report from the Centers on Public Service at George Mason University, the authors noted that in many cases the architects of the Recovery Act targeted pre-existing social networks to implement key provisions of the Act. ${ }^{7}$ They observe that ARRA was implemented largely through networks of states, counties, cities, non-profits and private contractors. They state that depending on the networks involved, this could have been "a recipe often fraught with potential for goal conflict, program slippage and confusion."

The authors did specifically address ARRA and the national weatherization network. Despite pre-ARRA assessments that the national weatherization network was shovel ready, it did not have the capacity to easily ramp up to a $\$ 5$ billion program. They praised those in the weatherization network as being 'heroic' and criticized the administration for ratcheting up accountability and inspections despite a lack of staffing at every level of the national weatherization network. Findings from surveys administered to Grantees and Subgrantees by the ORNL WAP evaluation team reported in the next several subsections provide more detailed insights into these general observations. ${ }^{8}$

The survey respondents supported the George Mason's study finding that accountability and oversight went hand-in-hand with ARRA funding. Referring to Table 2.7 almost all of the Grantees and $80 \%$ of the Subgrantees reported increased oversight. For example, DOE's Inspector General was a regular presence during the Recovery Act. ${ }^{9}$ DOE's Office of Weatherization and Intergovernmental Programs (OWIP) increased its in-field oversight, and in response, the Grantees and Subgrantees increased their oversight, too. Over one-half of the Grantees and almost one-half of the Subgrantees reported that the increased oversights increased their program costs moderately to extremely (See Table 2.7). Thirty-three percent of the states reported that these cost increases were a substantial or extreme burden. It should be noted that $24 \%$ Subgrantees conducted more stringent program eligibility checks during the Recovery Act period.

\footnotetext{
${ }^{7}$ Posner, P. et al. 2013. The Implementation of the Recovery Act: Networks Under Stress. Centers on the Public Service, Department of Public and International Affairs, George Mason University, Arlington, VA, February.

${ }^{8}$ Table A.1 in Appendix A presents the number of Grantees and Subgrantees that answered the surveys and the response rates, which were quite high.

${ }^{9}$ E.G., Friedman, G. 2011. Statement of Gregory H. Friedman, Inspector General, U.S. Department of Energy, Before the Subcommittee on Regulatory Affairs, Stimulus Oversight, and Government Spending; Committee on Oversight and Government Reform; U.S. House of Representatives. Nov. 2. Testified that the IG found few shovel ready projects and expectations for production were unrealistic. The IGs in-field inspections revealed problems, but the inspections were limited in number and scope. Another report also took the weatherization network to task DOE OIG, 2011. The Department of Energy's Weatherization Assistance Program under the American Recovery and Reinvestment Act in the State of Tennessee. OAS-RA-11-17, Sept. 19 (accessed (9/5/2014). Subgrantee responses suggests that the IG's criticisms, in many cases, were not warranted.
} 
Table 2.3 Recovery Act Changed Milieu Surrounding Weatherization Programs (\%)

\begin{tabular}{|l|c|c|}
\hline & Grantees & Subgrantees \\
\hline Significant Change in Wx Network & $33 \%$ & $63 \%$ \\
\hline Change in Organizational Responsibilities for Wx Program & $45 \%$ & $48 \%$ \\
\hline Passage of New Laws/Regulations Impacting Program & $31 \%$ & $50 \%$ \\
\hline Relationship with Subgrantees/Grantees negative to more negative & $26 \%$ & $19 \%$ \\
\hline Visibility of Program to General Public Increased & $96 \%$ & $54 \%$ \\
\hline Quality of Media Attention: High to Very High & $14.6 \%$ & $24.4 \%$ \\
\hline Quality of Media Attention: Low to Very Low & $12.4 \%$ & $14.5 \%$ \\
\hline Media Attention: Positive to Very Positive & $45 \%$ & $60 \%$ \\
\hline Media Attention: Negative to Very Negative & $20 \%$ & $4 \%$ \\
\hline
\end{tabular}

Table 2.4 Media Topics of Focus (\%)

\begin{tabular}{|l|c|c|}
\hline & Grantees & Subgrantees \\
\hline Jobs created & $49.0 \%$ & $51.6 \%$ \\
\hline Energy saved & $42.9 \%$ & $58.7 \%$ \\
\hline Helping low income households & $65.3 \%$ & $72.0 \%$ \\
\hline Waste, fraud and abuse & $34.7 \%$ & $12.4 \%$ \\
\hline Lack of energy savings & $2.0 \%$ & $1.7 \%$ \\
\hline Organizational mis-steps & $28.6 \%$ & $5.1 \%$ \\
\hline
\end{tabular}


Table 2.5 Focus of Media Attention on Subgrantee Programs During the Recovery Act (\%)

\begin{tabular}{|l|l|c|c|c|c|c|c|}
\hline \multicolumn{2}{|l|}{} & $\begin{array}{c}\text { Jobs } \\
\text { Created }\end{array}$ & $\begin{array}{c}\text { Energy } \\
\text { Saved }\end{array}$ & $\begin{array}{c}\text { Helping Low } \\
\text { Income } \\
\text { Households }\end{array}$ & $\begin{array}{c}\text { Waste/ } \\
\text { Fraud/ } \\
\text { Abuse }\end{array}$ & $\begin{array}{c}\text { Lack Of } \\
\text { Energy } \\
\text { Savings }\end{array}$ & $\begin{array}{c}\text { Organiza- } \\
\text { tional } \\
\text { Mis-steps }\end{array}$ \\
\hline $\begin{array}{l}\text { Very Cold } \\
(\mathrm{N}=100)\end{array}$ & Percentage & $58 \%$ & $66 \%$ & $71 \%$ & $9 \%$ & $4 \%$ & $4 \%$ \\
\hline $\begin{array}{l}\text { Cold } \\
(\mathrm{N}=230)\end{array}$ & Percentage & $57 \%$ & $57 \%$ & $73 \%$ & $15 \%$ & $0 \%$ & $6 \%$ \\
\hline $\begin{array}{l}\text { Moderate } \\
(\mathrm{N}=176)\end{array}$ & Percentage & $48 \%$ & $62 \%$ & $77 \%$ & $7 \%$ & $2 \%$ & $3 \%$ \\
\hline $\begin{array}{l}\text { Hot- } \\
\text { Humid } \\
(\mathrm{N}=116)\end{array}$ & Percentage & $41 \%$ & $52 \%$ & $63 \%$ & $16 \%$ & $1 \%$ & $6 \%$ \\
\hline $\begin{array}{l}\text { Hot-Dry } \\
(\mathrm{N}=39)\end{array}$ & Percentage & $51 \%$ & $56 \%$ & $72 \%$ & $23 \%$ & $5 \%$ & $10 \%$ \\
\hline & Mean & $52 \%$ & $59 \%$ & $72 \%$ & $12 \%$ & $2 \%$ & $5 \%$ \\
\cline { 2 - 9 } Total & $\begin{array}{l}\text { Std. } \\
\text { Deviation }\end{array}$ & .500 & .493 & .449 & .330 & .128 & .221 \\
\hline
\end{tabular}

(1= yes, 0-no)

Table 2.6 Media Coverage of Subgrantee Weatherization Programs During the Recovery Act

\begin{tabular}{|l|c|c|c|}
\hline Climate Zone & Mean & N & Std. Deviation \\
\hline Very Cold & 2.2 & 112 & 4.280 \\
\hline Cold & 2.3 & 253 & 3.705 \\
\hline Moderate & 2.2 & 187 & 4.363 \\
\hline Hot-Humid & 1.5 & 120 & 4.894 \\
\hline Hot-Dry & 2.2 & 43 & 4.172 \\
\hline Total & $\mathbf{2 . 2}$ & $\mathbf{7 1 5}$ & $\mathbf{4 . 2 1 8}$ \\
\hline
\end{tabular}

( $1=$ very negative, $2=$ negative, $3=$ neither positive or negative, $4=$ positive, $5=$ very positive $)$

Table 2.7: Factors Influencing Program Costs During Recovery Act Period (\%)

\begin{tabular}{|l|c|c|}
\hline & Grantees & Subgrantees \\
\hline Reported Increased Oversight & $96 \%$ & $80 \%$ \\
\hline Costs for Increased Oversight Moderate to Extreme & $57 \%$ & $45 \%$ \\
\hline Davis-Bacon Increased Wages & $92 \%$ & $76 \%$ \\
\hline Overall Costs Increased Because of Davis-Bacon & $94 \%$ & $80 \%$ \\
\hline Supply Chain Bottlenecks & $22 \%$ & $21 \%$ \\
\hline
\end{tabular}




\subsection{DAVIS-BACON: UNINTENDED CONSEQUENCES}

The Recovery Act had a profound impact upon WAP at every level of its administration. In addition to ramping up to meet production goals, the national network also had to contend with the provisions of the Davis-Bacon Act of $1931 .^{10}$ This Act requires that all federal construction and public works projects need to pay 'prevailing wages' for laborers and mechanics. The U.S. Department of Labor (DoL) is responsible for determining prevailing for all labor categories in these two job areas for every county in the United States. Because weatherization had not fallen under the provisions of Davis-Bacon before the Recovery Act, the DoL had to start from scratch in identifying specific weatherization jobs that did indeed fall within the purview of Davis-Bacon and then determining for those job categories the prevailing wages county-by-county.

After the first task was accomplished, the DoL collected data in order to determine the prevailing wages. This process took approximately six months. During this period of time, roughly one-half of the Grantees advised their Subgrantees to hold off on weatherizing any homes until the wage rates were set as there was a good deal of uncertainty about whether the wages paid to weatherization workers were less than the prevailing wages determined by the DoL. This delay caused a substantial amount of frustration throughout the weatherization community. It also lead to unfavorable publicity in the media, which reported the delays but often did not report the reason was beyond the network's control. In late fall 2009, the DoL solved the weatherization-related prevailing wage questions and production began in earnest (See Figure 2.3).

The Grantees and Subgrantees were surveyed about the impacts of the prevailing wage provision on their weatherization costs during the ARRA period. Almost all of the Grantees and two-thirds of the Subgrantees reported that overall, Davis-Bacon lead to wage increases (See Table 2.7). Discussions with over a dozen Subgrantees held during case study visits suggest that the DoL adopted most of the wage rates that the Subgrantees were already paying their in-house staff but that wage rates for specialty jobs, such as for electricians working in multifamily buildings five floors or higher, rose quite substantially. From the survey, $32 \%$ of Grantees reported an increase in $1-10 \%, 22 \%$ an increase of $11-20 \%$, and $44 \%$ no change in costs for weatherizing multifamily buildings due to Davis-Bacon.

Davis-Bacon and the surrounding milieu of the Recovery Act period generally led to increased program costs. For example, Davis-Bacon required the Subgrantees to submit weekly employment time and wage rate sheets not only for in-house staff whose jobs fell into the DoL job categories but for all of their contractor staff as well. It was common for Subgrantees to hire a new staff member whose sole job was to administer the Davis-Bacon paperwork. ${ }^{11}$ Table 2.8 indicates that the majority of Grantees and Subgrantees reported that Davis-Bacon created jobs. Seventeen percent of the Subgrantees reported that the increased labor costs altered the costs of measures installed, and also ultimately altered the sets of measures installed in homes because some measures that would have had a savings-to-investment (SIR) ratio greater than 1.0 now failed the SIR test and could not be installed. Thus, the majority of Grantees and Subgrantees reported that Davis-Bacon increased their costs (Table 2.7).

An interesting challenge was posed to local weatherization agencies that worked in two or more counties. Prior to ARRA, the agencies paid their workers the same amount regardless of what county they worked in. However, the DoL determined prevailing wages at times could be different from county to county for agencies that worked in multiple counties. This complication impacted most states, almost one half in a major manner (see Table 2.8). It also impacted the Subgrantees, sometimes negatively, sometimes

\footnotetext{
${ }^{10} \mathrm{See}$ http://en.wikipedia.org/wiki/davis\%e2\%80\%93bacon act

${ }^{11}$ See Tonn, Rose, and Hawkins (2014).
} 
positively. Typically, those affected agencies adjusted wages to the highest rate stipulated by the DoL for their counties in a desire to reduce administrative recordkeeping burden. Some agencies viewed those adjustments negatively, others positively.

As noted above, Davis-Bacon required the completion of weekly time sheets. The sheets were required not only for in-house staff but also for contractors as well. Ad hoc comments provided during discussions with the case study agencies indicated that some of the smaller contractors opted to drop out of the lowincome weatherization business because of this hassle. The Subgrantees were asked whether Davis-Bacon had an impact on the overall experience levels of the contractors they hired. The results were mixed: 53\% said there was no change in experience, $25 \%$ confirmed a decrease but $22 \%$ indicated an increase.

Table 2.8 Employment Impacts of Davis-Bacon (\%)

\begin{tabular}{|l|l|l|l|l|l|}
\hline $\begin{array}{l}\text { Which statement best } \\
\text { describes changes in the } \\
\text { level of employment in } \\
\text { your resulting from } \\
\text { Davis-Bacon? }\end{array}$ & Grantee & $\begin{array}{l}\text { Sub- } \\
\text { grantee } \\
\text { did your } \\
\text { while coordinating wages } \\
\text { stipulated by Davis- } \\
\text { Bacon for local } \\
\text { weatherization agencies } \\
\text { whose operations } \\
\text { spanned multiple } \\
\text { counties? }\end{array}$ & Grantee & $\begin{array}{c}\text { Sub- } \\
\text { grantee }\end{array}$ \\
\hline $\begin{array}{l}\text { large number of jobs } \\
\text { created }\end{array}$ & $27 \%$ & $22 \%$ & no impact/very negative & $8 \%$ & $3 \%$ \\
\hline $\begin{array}{l}\text { small number of jobs } \\
\text { created }\end{array}$ & $27 \%$ & $44 \%$ & small impact/negative & $18 \%$ & $18 \%$ \\
\hline $\begin{array}{l}\text { no change in the number of } \\
\text { jobs }\end{array}$ & $37 \%$ & $30 \%$ & moderate impact/no impact & $32 \%$ & $61 \%$ \\
\hline small number of jobs lost & $7 \%$ & $4 \%$ & large impact/positive & $20 \%$ & $15 \%$ \\
\hline large number of jobs lost & $2 \%$ & $>0 \%$ & $\begin{array}{l}\text { very large impact/very } \\
\text { positive }\end{array}$ & $22 \%$ & $3 \%$ \\
\hline
\end{tabular}




\subsection{OTHER FEEDBACK FROM THE RECOVERY ACT PERIOD}

Before addressing the impact of WAP Recovery Act funding on program funding leveraging, this subsection addresses additional operational issues encountered during the Recovery Act period. These issues fall into these categories: technical assistance; staff management; program operations; and purchases.

Given all the changes across WAP from management reporting channels and program regulations to ramping up employment and production, the quality of technical assistance provided by DOE to the national weatherization network and from Grantees to Subgrantees should be assessed. Table 2.9 reports that by-and-large, Grantees found the technical assistance provided by DOE was moderate to very high in quality with respect to management support, training, client education, and other technical support. The same is true for the technical assistance provided by the Grantees to their Subgrantees, though the Subgrantees gave their state offices higher marks in most assistance categories (see Table 2.10). From a third viewpoint, there were mixed responses related to the timeliness and clarity in guidance DOE provided to Subgrantees. As reported in Table 2.11, large percentages of Subgrantees did not find DOE guidance to be timely or clear. Technical assistance and guidance was particularly important because many Grantees (45\%) and Subgrantees (68\%) believed that DOE WAP rules were inflexible during this period of time.

As indicated in Figure 2.2, direct employment in weatherization greatly increased during the Recovery Act. To manage this increase, just over $25 \%$ of Subgrantees reported increasing their use of contractor crews (vs. 58\% that reported no change in the relative share of in-house crews versus contractor work). As could be expected, the hiring of so many new employees decreased the percentage of managers, auditors, and crew that Subgrantees judged to have high and very high levels of experience in weatherization from PY 2008 to PY 2010 (see Figure 2.5). It can be inferred from this figure that the Subgrantees promoted experienced auditors to become managers and experienced crew leaders and members to become auditors, thereby leaving the crews with less experience, on balance. Adding to this management challenge is that almost one-third of Subgrantees reported higher staff turnover during the Recovery Act period. Lastly, 29\% of Subgrantees reported competing with other highly funded DOE Recovery Act programs (such as the State Energy Program and the Energy Efficiency and Conservation Block Grant Program) for labor.

Helping to balance these management issues is the finding that two-thirds of Subgrantees reported at least some economies of scale benefits as their programs increased, with $9.1 \%$ reporting substantial benefits. Almost half (44\%) of Subgrantees were able to purchase new information technologies and $82 \%$ reported being able to purchase new field technologies. Almost two-thirds of the states (63\%) also reported being able to purchase new information technology.

Table 2.9 Quality of DOE Services Provided to Grantees (\%)

\begin{tabular}{|l|c|c|c|c|}
\hline & $\begin{array}{c}\text { Management } \\
\text { Support }\end{array}$ & Training & Client Education & Technical Support \\
\hline Very Low Quality & $4 \%$ & $4 \%$ & $10 \%$ & $5 \%$ \\
\hline Low Quality & $6 \%$ & $7 \%$ & $16 \%$ & $10 \%$ \\
\hline Moderate Quality & $39 \%$ & $55 \%$ & $48 \%$ & $51 \%$ \\
\hline High Quality & $47 \%$ & $27 \%$ & $19 \%$ & $29 \%$ \\
\hline Very High Quality & $4 \%$ & $7 \%$ & $7 \%$ & $5 \%$ \\
\hline
\end{tabular}


Table 2.10 Quality of Grantee Services Provided to Subgrantees (\%)

\begin{tabular}{|l|c|c|c|c|}
\hline & $\begin{array}{c}\text { Management } \\
\text { Support }\end{array}$ & Training & Client Education & Technical Support \\
\hline Very Low Quality & $4 \%$ & $2 \%$ & $3 \%$ & $3 \%$ \\
\hline Low Quality & $12 \%$ & $7 \%$ & $9 \%$ & $10 \%$ \\
\hline Moderate Quality & $42 \%$ & $36 \%$ & $56 \%$ & $39 \%$ \\
\hline High Quality & $30 \%$ & $42 \%$ & $26 \%$ & $37 \%$ \\
\hline Very High Quality & $12 \%$ & $13 \%$ & $6 \%$ & $11 \%$ \\
\hline
\end{tabular}

Table 2.11 DOE Guidance to Subgrantees During ARRA Period (\%)

\begin{tabular}{|l|c|l|c|}
\hline $\begin{array}{l}\text { How timely has DOE's } \\
\text { guidance been during the } \\
\text { ARRA period? }\end{array}$ & Subgrantee & $\begin{array}{l}\text { How clear has DOE's } \\
\text { guidance been during the } \\
\text { ARRA period? }\end{array}$ & Subgrantee \\
\hline Very timely & $3 \%$ & Very clear & $5 \%$ \\
\hline Timely & $48 \%$ & Clear & $50 \%$ \\
\hline Not very timely & $40 \%$ & Not very clear & $39 \%$ \\
\hline Not timely at all & $9 \%$ & Not clear at all & $6 \%$ \\
\hline
\end{tabular}

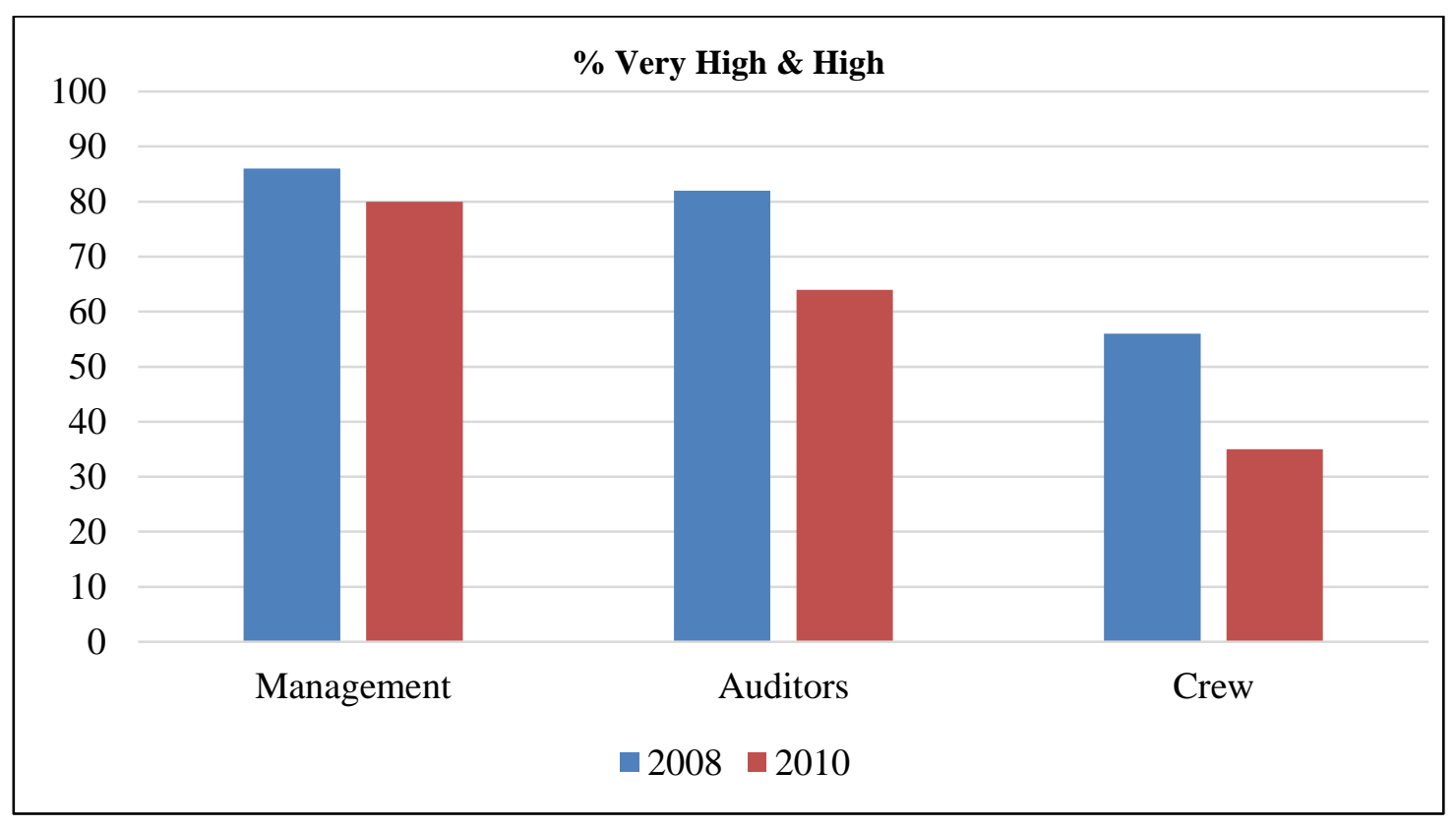

Figure 2.5 Impacts of ARRA Period: Local Agency Staff Experience

\subsection{LEVERAGED FUNDING DURING THE RECOVERY ACT PERIOD}

The topic of this subsection is the funding that Grantees and Subgrantees were able to acquire beyond what DOE provided to support their weatherization programs. DOE strongly encourages Grantees and 
Subgrantees to leverage DOE funding to acquire additional funds. For example, Grantees and Subgrantees use DOE dollars to train auditors, crew leaders, and crew members. The benefits of this training accrue not only to weatherization jobs paid for by DOE funds but also to weatherization work supported by other sponsors (e.g., utilities) who do not bear the training costs. Other sponsors are attracted to the DOE-supported weatherization network because of its trained workforce and high quality of work. Many of the Subgrantees, especially the CAAs, have years of experience in community social services that allows them to readily recruit homes for weatherization.

Leveraged funds provided to Grantees and Subgrantees are used in two ways. First, they can be braided with DOE funds to weatherize individual homes. All braided-funded homes are weatherized under DOE regulations, even if only $\$ 1$ of DOE funds was expended on the home. Second, the funds can be used separately. This is often the case if the leveraged funds come with their own stipulations. For example, funds from an electric utility company may only be used on electricity measures and then maybe even only for new compact florescent light (CFL) bulbs. Funds from a natural gas utility company may only be used to reduce natural gas use.

Table 2.12 presents DOE and leveraged funding received by Grantees and Subgrantees in Program Years 2010 and 2008. Again, this table demonstrates the dramatic increase in the national weatherization program in only a couple of years. Total funding for weatherization, DOE plus leveraged funding, increased by just under $\$ 2$ billion. The percent of DOE funds invested in DOE units increased from 54\% to $85 \% .{ }^{12}$ The largest source of non-DOE funds is the federal Low Income Home Energy Assistance Program (LIHEAP). Administered by the U.S. Department of Health and Human Services (HHS), LIHEAP assists eligible low-income households with paying their energy bills. HHS allows states to allocate up to $15 \%$ of their LIHEAP funding (up to $25 \%$ with an approved waiver) to their weatherization programs with the understanding that these funds would be used to reduce the energy bills of households that have relatively high energy burdens and/or high rates of energy consumption. It is easy to target these households because the Subgrantees that are CAAs usually administer LIHEAP locally and have access to their clients energy bills. State public benefit funds, other state programs, and utilities provide the majority of the remaining leveraged funding.

It is important to note the amount of leveraged funds flowing directly to the Subgrantees. Subtracting the LIHEAP funds from the Grantee side of the ledger shows that Subgrantee leveraged funding increased during the Recovery Act period and even exceeded the non-LIHEAP leveraged funding received by the Grantees. Again, referring to the ORNL weatherization agency case studies report ${ }^{13}$, it was found that many Subgrantees are the nodal point for numerous funding streams related to weatherization and social services, which are braided into a one-stop shopping experience for their clients. The large amount of utility leveraged funding that flows to the Subgrantees supports the contention that Subgrantees are entrepreneurial.

Figure 2.6 and Tables 2.13 and 2.14 provide three additional perspectives on leveraged funding. Both Figure 2.6 and Table 2.13 present the results of a funding profile cluster analysis for Subgrantees by amount of DOE, LIHEAP and other leveraged funding received. The analysis resulted in four groups ranging in funding amounts from small to very large. These groups are presented from largest average amount of funding to smallest. One can see, for example, that the PY 2008 and PY 2010 groups with the smallest amount of funding were the largest groups, with 598 and 583 Subgrantees in each group, respectively. Still, for the smallest programs, total funding increased by about $\$ 1$ million on average. The

\footnotetext{
${ }^{12}$ However, because leveraged funding did not increase nearly as much as DOE funding, even with an increase in DOE funding per weatherized unit, the average spent to weatherize a unit in PY 2010 did not increase appreciably from PY 2008.

${ }^{13}$ Tonn, B., Rose, E., and Hawkins, B. 2014. Weatherization Beyond the Numbers: Case Studies of Fifteen High-Performing Weatherization Agencies - Conducted May 2011 - July 2012.
} 
larger programs' funding levels increased by several million dollars. The histogram bars also again indicate how DOE funding came to greatly overshadow leveraged funding in the Recovery Act period.

Table 2.13 presents the groups by program year by climate zone. This table shows the impact of the change in funding formula, as the relative percentage of the largest Subgrantee-level programs shifted from the cold to the hot regions during the Recovery Act period. Lastly, the results presented in Table 2.13 confirm that leveraged funding was less important during the Recovery Act, at least to Grantees. The percentage of Grantees that indicated that leveraged funding was very important dropped from 55\% in PY 2008 to 37\% in PY 2010 and the percentage reporting that leveraged funding was not important at all increased by 8\% during this period. Reports from the Subgrantees in PY 2010 are similar to those from the Grantees in PY 2010, except that it is clear that more Subgrantees find leveraged funding to be of some importance.

Table 2.12 DOE and Leveraged Weatherization Funding in PY 2010 and PY 2008 (\$ millions)

\begin{tabular}{|c|c|c|c|c|c|c|c|c|}
\hline & \multicolumn{4}{|c|}{2010} & \multicolumn{4}{|c|}{2008} \\
\hline & \multicolumn{2}{|c|}{ Grantees } & \multicolumn{2}{|c|}{ Sub-grantees } & \multicolumn{2}{|c|}{ Grantees } & \multicolumn{2}{|c|}{ Sub-grantees } \\
\hline & $\mathbf{N}$ & $\$$ & $\mathbf{N}$ & $\$$ & $\mathbf{N}$ & $\$$ & $\mathbf{N}$ & $\$$ \\
\hline DOE & 51 & $\$ 2,008$ & - & - & 51 & $\$ 236$ & - & - \\
\hline LIHEAP & 43 & $\$ 401$ & 5 & $\$ 1$ & 46 & $\$ 319$ & 11 & $\$ 3$ \\
\hline State Public Benefit & 5 & $\$ 46$ & 52 & $\$ 19$ & 8 & $\$ 83$ & 50 & $\$ 9$ \\
\hline Other State Programs & 6 & $\$ 37$ & 104 & $\$ 21$ & 10 & $\$ 31$ & 145 & $\$ 27$ \\
\hline Utilities & 13 & $\$ 24$ & 268 & $\$ 94$ & 14 & $\$ 21$ & 174 & $\$ 52$ \\
\hline PVE and Other Fed. Programs & 8 & $\$ 10$ & 78 & $\$ 17$ & 9 & $\$ 12$ & 90 & $\$ 30$ \\
\hline $\begin{array}{l}\text { Program Income, In-kind, Non-profit, } 3^{\text {rd }} \\
\text { Party, Other }\end{array}$ & 3 & $\$ 22$ & 171 & $\$ 14$ & 4 & $\$ 20$ & 106 & $\$ 6$ \\
\hline Total & & $\$ 2,548$ & & $\$ 167$ & & $\$ 722$ & & $\$ 128$ \\
\hline State Retained & & $\$ 138$ & & & & $\$ 50$ & & \\
\hline Pass Through to Subgrantees & & $\$ 2,409$ & & & & $\$ 672$ & & \\
\hline Total Program Funding & & $\$ 2,715$ & & & & $\$ 850$ & & \\
\hline Amount Spent on DOE units & & $\$ 2,316$ & & & & $\$ 481$ & & \\
\hline Number of DOE units & & 340,158 & & & & 97,965 & & \\
\hline
\end{tabular}




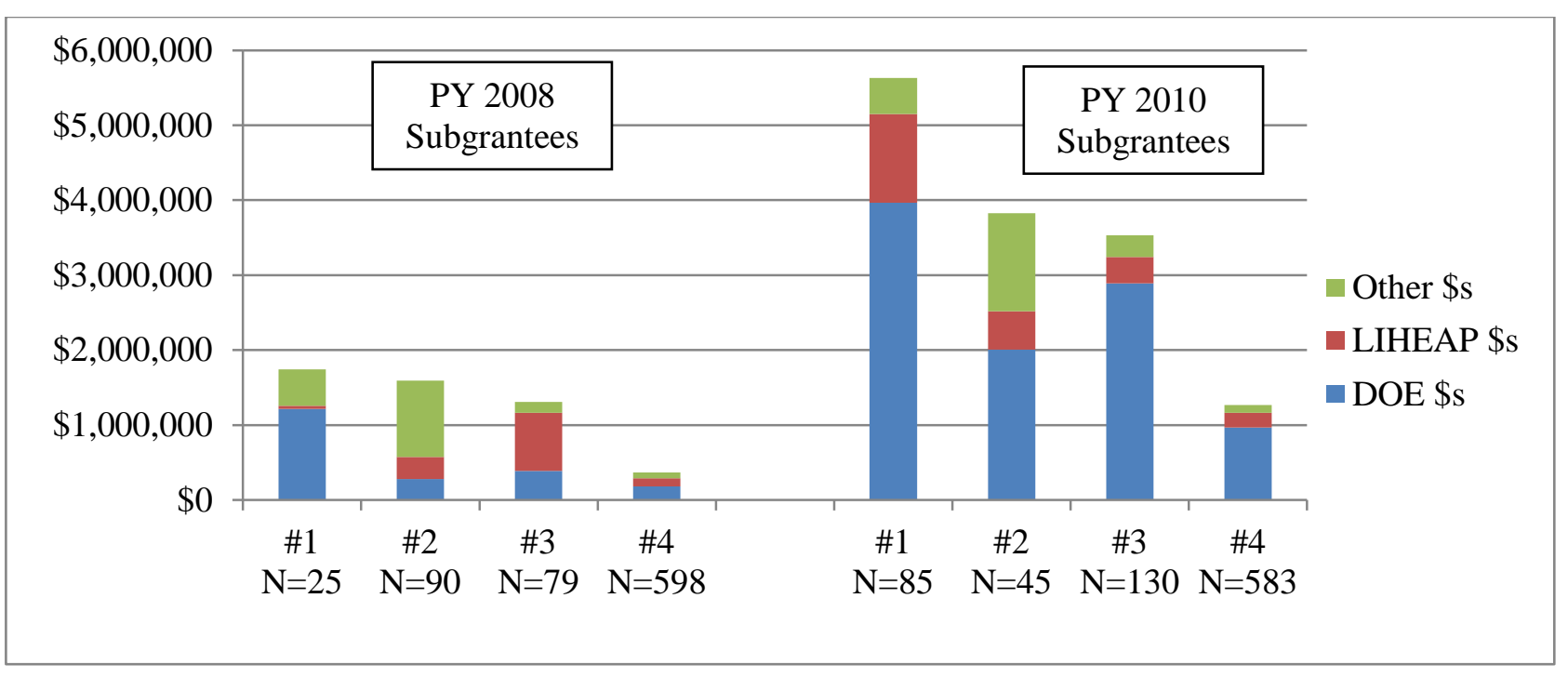

Figure 2.6: Clusters of Subgrantees Based on Spent DOE \& Leveraged Funds

Table 2.13 Clusters of Subgrantee Weatherization Funding by Climate Zone

\begin{tabular}{|l|c|c|c|c|c|c|}
\hline & Count & $\begin{array}{c}\text { Very } \\
\text { Cold }\end{array}$ & Cold & $\begin{array}{c}\text { Mod- } \\
\text { erate }\end{array}$ & $\begin{array}{c}\text { Hot- } \\
\text { Humid }\end{array}$ & $\begin{array}{c}\text { Hot- } \\
\text { dry }\end{array}$ \\
\hline PY 2008 & & & & & & \\
\hline 1. Moderate; Mostly DOE \& Other funding & 25 & $28 \%$ & $68 \%$ & $4 \%$ & $0 \%$ & $0 \%$ \\
\hline 2. Moderate size; high other funding & 90 & $34 \%$ & $32 \%$ & $21 \%$ & $1 \%$ & $11 \%$ \\
\hline 3. Moderate; Mostly LIHEAP funding & 79 & $13 \%$ & $48 \%$ & $11 \%$ & $9 \%$ & $19 \%$ \\
\hline 4. Small; Mostly DOE \& LIHEAP & 598 & $13 \%$ & $37 \%$ & $28 \%$ & $18 \%$ & $4 \%$ \\
\hline & & & & & & \\
\hline PY 2010 & & & & & & \\
\hline 1. Very Large; Mostly DOE \& LIHEAP & 85 & $14 \%$ & $39 \%$ & $8 \%$ & $18 \%$ & $21 \%$ \\
\hline 2. Large; Mostly DOE \& Other funding & 45 & $33 \%$ & $31 \%$ & $27 \%$ & $2 \%$ & $7 \%$ \\
\hline 3. Large; Mostly DOE & 130 & $36 \%$ & $35 \%$ & $10 \%$ & $15 \%$ & $3 \%$ \\
\hline 4. Moderate; Mostly DOE & 583 & $12 \%$ & $42 \%$ & $29 \%$ & $10 \%$ & $7 \%$ \\
\hline
\end{tabular}

Table 2.14 Grantees and Subgrantees: Importance of Leveraged Grants (\%)

\begin{tabular}{|l|c|c|c|c|}
\hline & $\begin{array}{c}\text { Grantees } \\
\mathbf{2 0 0 8}\end{array}$ & $\begin{array}{c}\text { Grantees } \\
\mathbf{2 0 1 0}\end{array}$ & $\begin{array}{c}\text { Subgrantees } \\
\mathbf{2 0 0 8}\end{array}$ & $\begin{array}{c}\text { Subgrantees } \\
\mathbf{2 0 1 0}\end{array}$ \\
\hline Not Important at All & $10 \%$ & $18 \%$ & $\mathrm{Na}$ & $11 \%$ \\
\hline Not Very Important & $8 \%$ & $16 \%$ & $\mathrm{Na}$ & $14 \%$ \\
\hline Important & $27 \%$ & $29 \%$ & $\mathrm{Na}$ & $33 \%$ \\
\hline Very Important & $55 \%$ & $37 \%$ & $\mathrm{Na}$ & $42 \%$ \\
\hline
\end{tabular}

Anecdotally, interactions between the national weatherization network and the evaluation team suggested that the infusion of funding provided to the network by the Recovery Act would have negative impacts on 
leveraged funding and the relationships built up over the years between Grantees/Subgrantees and other weatherization funders. Thus, the evaluation team investigated whether the Recovery Act had a negative impact on leveraged funding. The results presented in the rest of this subsection provide mixed results.

To begin this discussion, please refer to Table 2.15. Both Grantees and Subgrantees were asked when their leveraging relationships began with the ten different leveraging sources and then how many years it took to establish the relationship. Many of the leveraging relationships date back many decades. This is especially the case with the important LIHEAP relationships with the Grantees. The preponderance of the leveraging relationships involving both the Grantees and Subgrantees are much more recent, having evolved since the year 2000. One could hypothesize that those relationships might be most at risk due to the deluge of Recovery Act funding.

Most of the leveraging relationships appear to be hard won. For example, on average it took Grantees and Subgrantees over a decade to cement LIHEAP leveraged funding. It took the Subgrantees on average 13 years to establish leveraging relationships with their utilities. It should be noted that it is possible that much time was needed for the overseeing Public Utility Commissions to act to direct their regulated utilities to fund low-income efficiency programs, and then more time for the Subgrantees to convince utilities to work with them as opposed to commercial firms. Subgrantees also devoted a good deal of time to foster in-kind leveraging relationships.

With these thoughts in mind, 14 (27\%) of the Grantees reported that leveraging relationships were damaged or lost during the Recovery Act period. Of these Grantees, seven felt that relationships could be rebuilt, one said the relationship was lost, and six were uncertain if the relationship could be rebuilt after the Recovery Act. With respect to the Subgrantees, $15.8 \%$ said that leveraging relationships were damaged or lost, $34.8 \%$ said that these relationships could be re-built, $12.7 \%$ said there was no impact , and $52.5 \%$ were uncertain. These results suggest that the Recovery Act had a negative impact on leveraging.

The results contained in Tables 2.16 and 2.17 begin to present picture complicated leveraging picture. For example, Table 2.16 indicates that the percentage of Grantees that sought leveraged funds but were unsuccessful increased from 18\% in PY 2008 to 24\% in PY 2010, though the percentage of Grantees that did not seek leveraged funds in PY 2010 also increased by over 15\%. Table 2.17 indicates that more Grantees felt that ARRA had a negative impact on existing leveraging that a positive impact (26\% to $20 \%$ ) whereas the Subgrantees generally believed the opposite (16\% to 30\%). It should also be noted that Table 2.12 indicates that total leveraged funding was higher in PY 2010 than in PY 2008. Thus, on balance, it is hard to argue that ARRA had a negative impact on leveraging, at least with respect to PY 2010. 
Table 2.15 Leveraging Sources and History by Grantee and Subgrantees PY 2010

\begin{tabular}{|c|c|c|c|c|c|c|}
\hline & Grantees & 然 & 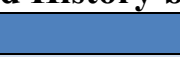 & Sub-grantees & +2 & \\
\hline & $\%$ Received & $\begin{array}{l}\text { Year First } \\
\text { Received }\end{array}$ & $\begin{array}{l}\text { Years to } \\
\text { Achieve - } \\
\text { Mean and } \\
\text { (Std) }\end{array}$ & $\begin{array}{l}\% \\
\text { Received }\end{array}$ & $\begin{array}{l}\text { Year First } \\
\text { Received }\end{array}$ & $\begin{array}{l}\text { Years to } \\
\text { Achieve - } \\
\text { Mean and } \\
\text { (Std) }\end{array}$ \\
\hline LIHEAP & $84 \%$ & $\begin{array}{l}\text { 1970s/80s: } 54 \% \\
\text { 1990s: } 31 \% \\
\text { 2000+: } 15 \%\end{array}$ & $11.0(12.7)$ & $1 \%$ & $\begin{array}{l}\text { 1970s/80s: } 39 \% \\
\text { 1990s: } 18 \% \\
\text { 2000+: } 43 \%\end{array}$ & $16.0(11.2)$ \\
\hline $\begin{array}{l}\text { PVE \& } \\
\text { Other } \\
\text { Federal } \\
\text { Programs }\end{array}$ & $14 \%$ & $\begin{array}{l}\text { 1970s/80s: } 20 \% \\
\text { 1990s: } \\
\text { 2000+: } 80 \%\end{array}$ & & $9 \%$ & $\begin{array}{l}\text { 1970s/80s: } 27 \% \\
\text { 1990s: } 11 \% \\
\text { 2000+: } 62 \%\end{array}$ & $10.5(10.3)$ \\
\hline $\begin{array}{l}\text { State } \\
\text { Public } \\
\text { Benefit } \\
\text { Funds }\end{array}$ & $10 \%$ & $\begin{array}{l}\text { 1970s/80s: } \\
\text { 1990s: } 25 \% \\
\text { 2000+: } 75 \%\end{array}$ & & $6 \%$ & $\begin{array}{l}\text { 1970s/80s: } 8 \% \\
\text { 1990s: } 29 \% \\
2000+: 63 \%\end{array}$ & $5.6(4.9)$ \\
\hline $\begin{array}{l}\text { Other } \\
\text { State } \\
\text { Programs }\end{array}$ & $12 \%$ & $\begin{array}{l}\text { 1970s/80s: } \\
\text { 1990s: } 25 \% \\
\text { 2000+: } 75 \%\end{array}$ & & $12 \%$ & $\begin{array}{l}\text { 1970s/80s: } 12 \% \\
\text { 1990s: } 30 \% \\
\text { 2000+: } 58 \%\end{array}$ & $5.8(7.2)$ \\
\hline Utilities & $30 \%$ & $\begin{array}{l}\text { 1970s/80s: } 11 \% \\
\text { 1990s: } 11 \% \\
2000+: 78 \%\end{array}$ & & $31 \%$ & $\begin{array}{l}\text { 1970s/80s: } 19 \% \\
\text { 1990s: } 23 \% \\
\text { 2000+: } 58 \%\end{array}$ & $13.4(11.6)$ \\
\hline $\begin{array}{l}\text { Program } \\
\text { Income }\end{array}$ & $2 \%$ & & & $20 \% *$ & $\begin{array}{l}\text { 1970s/80s: } 13 \% \\
\text { 1990s: } 8 \% \\
\text { 2000+: } 79 \%\end{array}$ & $9.3(8.8)$ \\
\hline In-kind & $2 \%$ & & & - & $\begin{array}{l}\text { 1970s/80s: } 20 \% \\
\text { 1990s: } 10 \% \\
2000+: 70 \%\end{array}$ & $12.2(12.0)$ \\
\hline $\begin{array}{l}\text { Non- } \\
\text { Profits }\end{array}$ & $0 \%$ & & & - & & \\
\hline $\begin{array}{l}\text { Third } \\
\text { Party }\end{array}$ & $0 \%$ & & & - & $\begin{array}{l}\text { 1970s/80s: - } \\
\text { 1990s: - } \\
\text { 2000+: } 100 \%\end{array}$ & $1.1(0.85)$ \\
\hline
\end{tabular}

*Includes Program Income, In-kind, Non-profits, and Third Party. 
Table 2.16 Grantees and Subgrantees: Success at Acquiring Leveraged Funds (\%)

\begin{tabular}{|l|c|c|c|c|}
\hline & Grantees 2008 & Grantees 2010 & $\begin{array}{c}\text { Subgrantees } \\
\mathbf{2 0 0 8}\end{array}$ & $\begin{array}{c}\text { Subgrantees } \\
\mathbf{2 0 1 0}\end{array}$ \\
\hline Not Successful & $4 \%$ & $6 \%$ & $\mathrm{Na}$ & $4 \%$ \\
\hline Not Very Successful & $14 \%$ & $18 \%$ & $\mathrm{Na}$ & $14 \%$ \\
\hline Successful & $45 \%$ & $31 \%$ & $\mathrm{Na}$ & $48 \%$ \\
\hline Very Successful & $19 \%$ & $14 \%$ & $\mathrm{Na}$ & $11 \%$ \\
\hline State does not seek leveraged funds & $14 \%$ & $29 \%$ & $\mathrm{Na}$ & $23 \%$ \\
\hline
\end{tabular}

Table 2.17 Grantees and Subgrantees: Impact of ARRA on existing leveraging (\%)

\begin{tabular}{|l|c|c|}
\hline & Grantees & Subgrantees \\
\hline Extremely negative impact & $0 \%$ & $1 \%$ \\
\hline Negative impact & $26 \%$ & $15 \%$ \\
\hline No impact & $54 \%$ & $54 \%$ \\
\hline Positive Impact & $16 \%$ & $25 \%$ \\
\hline Extremely positive impact & $4 \%$ & $5 \%$ \\
\hline
\end{tabular}

What do the Grantees and Subgrantees think about the future of their leveraged funding? Here is a summary of their survey responses:

- Grantees: $22.5 \%$ said they forecast post-ARRA leveraged funds to be below PY 2008, 30.6\% increased, $46.9 \%$ same level.

- Subgrantees: $34.5 \%$ said they forecast post-ARRA leveraged funds to be below PY 2008, 29.3\% increase, $36.2 \%$ same level.

This is a mixed message because in the short-run, the positive and negative impacts of ARRA may cancel each other out. However, the message for the long-term is quite positive as:

- Grantees: $12 \%$ see ARRA as unbeneficial for leveraging long-term, 56\% no long-term impact, $32 \%$ beneficial.

- Subgrantees: $14.2 \%$ see ARRA as unbeneficial for leveraging long-term, $44.1 \%$ no long-term impact; $41.7 \%$ beneficial

Table 2.18 presents results for the most important source of leveraged funding, LIHEAP. As noted in Table 2.12, LIHEAP funds actually increased in PY 2010, which is reflected in the survey results below. However, a substantial number of Grantees (most importantly) and Subgrantees forecast decreases in LIHEAP post-ARRA and most attribute the expected decrease to ARRA. From Figure 2.7 one can see that LIHEAP is the most problematic leveraging source for the Grantees going forward. All the others, and even the utilities, seem to present a stable picture. The leveraging picture for the Subgrantees is different. While most leveraging sources contributed more funds to more Subgrantees during ARRA, more Subgrantees forecast declines than increases in leveraging across the board immediately postARRA. 
Table 2.18 LIHEAP Related Results from PY 2010 Surveys of Grantees and Subgrantees:

Leveraging

\begin{tabular}{|c|c|c|c|c|c|}
\hline \multirow[b]{2}{*}{$\begin{array}{l}\text { Change in LIHEAP } \\
\text { funding During ARRA }\end{array}$} & \multirow[b]{2}{*}{$\begin{array}{l}\text { Extremely negative } \\
\text { Negative } \\
\text { No Change } \\
\text { Positive } \\
\text { Extremely Positive }\end{array}$} & \multicolumn{2}{|c|}{ Grantees } & \multicolumn{2}{|c|}{ Subgrantees } \\
\hline & & $\begin{array}{l}0 \% \\
12.2 \% \\
65.9 \% \\
19.5 \% \\
2.4 \%\end{array}$ & $(\mathrm{~N}=41)$ & $\begin{array}{l}1.3 \% \\
8.8 \% \\
50.0 \% \\
25.9 \% \\
14.0 \%\end{array}$ & $(\mathrm{~N}=522)$ \\
\hline $\begin{array}{l}\text { Forecast change in } \\
\text { LIHEAP funding post- } \\
\text { ARRA }\end{array}$ & $\begin{array}{l}\text { Increase } \\
\text { Stay the Same } \\
\text { Decrease }\end{array}$ & $\begin{array}{l}7.3 \% \\
63.4 \% \\
29.3 \%\end{array}$ & $(\mathrm{~N}=41)$ & $\begin{array}{l}19.3 \% \\
34.7 \% \\
46.1 \%\end{array}$ & $(\mathrm{~N}=519)$ \\
\hline $\begin{array}{l}\text { If forecast decrease, } \\
\text { attributable to ARRA? }\end{array}$ & $\begin{array}{l}\text { Yes } \\
\text { No }\end{array}$ & $\begin{array}{l}57.1 \% \\
42.9 \%\end{array}$ & $(\mathrm{~N}=14)$ & $\begin{array}{l}70.5 \% \\
29.5 \%\end{array}$ & $(\mathrm{~N}=258)$ \\
\hline
\end{tabular}

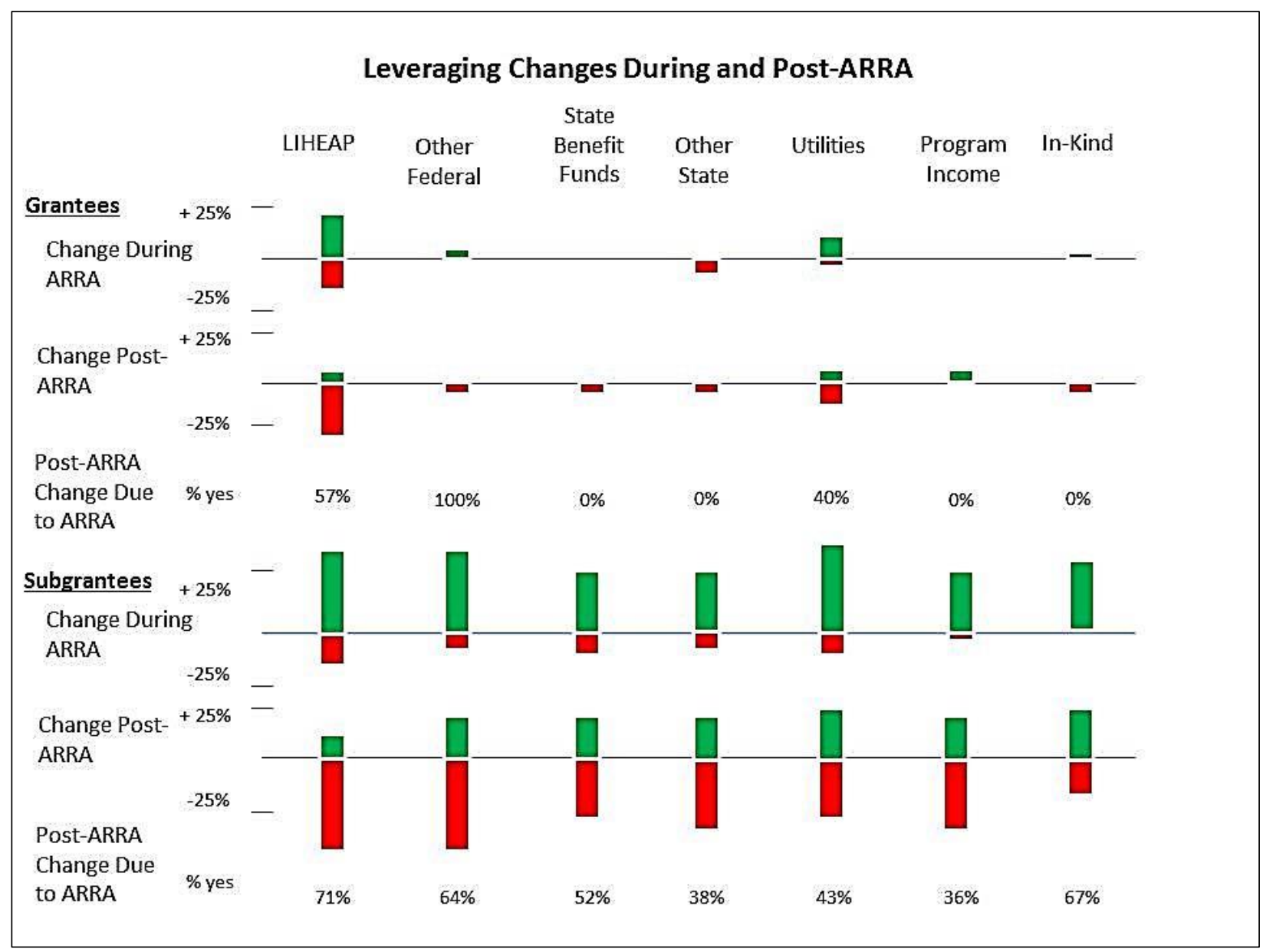

Figure 2.7 Leveraging Changes During and Post-ARRA by Leveraging Source 


\subsection{SUMMARY}

The results presented in this section describe the experiences of the Grantees and Subgrantees of the national weatherization network during the Recovery Act period. A substantial increase in DOE funding for weatherization led to an unprecedented ramp up in production and employment. In the midst of the Recovery Act crucible, many Grantees and Subgrantees dealt with increased attention not only from their elected officials and fellow bureaucrats but also from the media. New management reporting arrangements, state laws, and employees and contractors added to changed landscape of WAP during the Recovery Act. The Davis-Bacon Act slowed down the ramp up and greatly complicated the work of the Subgrantees. Overall, the Recovery Act had a mixed impact on program leveraging.

Despite all of the stresses involved with the Recovery Act and issues surrounding media coverage, 44\% of Grantees felt that the added attention to weatherization during the Recovery Act was beneficial, only $12 \%$ felt it was unbeneficial. Amongst Subgrantees, $51 \%$ felt the attention was beneficial, and only $7 \%$ felt it was unbeneficial. Almost half of the Subgrantees felt the public's support for weatherization increased; only $3 \%$ felt support decreased. These beliefs undoubtedly underlie the mostly positive outlook that the respondents have with respect to the future of their leveraged funding.

Still, the national weatherization network has challenges ahead. For example, the Subgrantees were asked about the public's understanding of weatherization. A majority have some concerns, $57 \%$ reported that the public's understanding of their programs is only fair to poor, with only $43 \%$ reporting good to excellent. The survey was conducted before federal allocations to DOE for WAP were severely cut for several years and as of this writing, not yet restored to pre-ARRA levels. 


\section{CHARACTERIZATION OF WAP OUTPUTS DURING THE RECOVERY ACT}

Despite the challenges described in the previous section of this report, in most ways WAP during the Recovery Act was very similar to WAP as implemented in PY 2008On the ground, the WAP program in its essence did not change much from the version of the program implemented in PY2008. As documented below, the clients served, the audit approaches and diagnostic procedures used, the types and frequency of measures installed, approaches to client education, and training offered and received were quite similar. For this reason, this report presents highlights with respect to characterizing WAP during the Recovery Act and readers who desire more information that characterizes WAP are referred to the retrospective program characterization report (Bensch et al. 2014). This section of the report concludes with a discussion about multifamily weatherization and then a few miscellaneous topics.

\subsection{DEMOGRAPHICS AND HOUSING UNIT CHARACTERISTICS}

This subsection presents statistics that describe the demographics of the households and their homes that received weatherization services in PY 2010. Table 3.1 presents client household characteristics by building type. In most cases, the statistics vary by demographic characteristic. For example, households living in single family (SF) homes have higher annual incomes than households living either in small multifamily (SMF) or large multifamily (LMF) buildings. LMF households are much less likely to be designated as high energy users or have a high energy burden. Findings revealed that persons with disabilities more often reside in mobile homes (MH) and SF homes than MF. Also in this sample, those living in SMF and LMF buildings are much less likely to own their homes and are much more likely to self-identify as being Black or Hispanic.

Compared to the population served in PY 2008, the PY 2010 WAP households:

- Have higher incomes - e.g., average annual household income for those living in SF homes in PY 2010 was $\$ 15,700$ versus \$13, 200 in PY 2008 and for MH was \$13,400 in PY 2010 versus $\$ 11,470$ in PY 2008.

- $\quad$ Have fewer vulnerable individuals - e.g., the percent of SF homes with a person with disabilities was 30\% in PY 2010 versus 39\% in PY 2008 and for MH was 39\% versus 49\%.

- Were more likely to be non-white - The percentage of Black and Hispanic households living in SF and MH served increased (e.g., from 31\% in PY 2008 to 39\% in PY 2010 for SF homes and $15 \%$ to $22 \%$ for $\mathrm{MH})$.

Table 3.2 presents household characteristics across five climate zones. In many cases, demographic characteristics also vary by climate zone. For instance, the lowest household incomes are associated with homes located in hot/humid climates of the Southeast. Possibly because of high electricity use in the moderate climate homes, their energy burden rate is substantially higher than homes in the other climate zones. Weatherized homes appear to be more racially and ethnically diverse in the two hot climates. 
Table 3.1 PY 2010 Clients Household Characteristics by Building Unit Type

\begin{tabular}{|c|c|c|c|c|c|}
\hline Statistic & $\begin{array}{c}\text { All Housing } \\
\text { Units }\end{array}$ & $\begin{array}{l}\text { Single } \\
\text { Family }\end{array}$ & $\begin{array}{l}\text { Mobile } \\
\text { Home }\end{array}$ & $\begin{array}{c}\text { Small } \\
\text { Multifamily }\end{array}$ & $\begin{array}{c}\text { Large } \\
\text { Multifamily }\end{array}$ \\
\hline \multicolumn{6}{|l|}{ Income and Poverty } \\
\hline Median Income & $\$ 14,400$ & $\$ 15,700$ & $\$ 13,400$ & $\$ 11,800$ & $\$ 10,400$ \\
\hline High Energy User & $38 \%$ & $41 \%$ & $42 \%$ & $35 \%$ & $14 \%$ \\
\hline High Energy Burden & $37 \%$ & $40 \%$ & $37 \%$ & $36 \%$ & $16 \%$ \\
\hline \multicolumn{6}{|l|}{ Vulnerability Status } \\
\hline$\%$ w/ Elderly Individual & $39 \%$ & $42 \%$ & $39 \%$ & $24 \%$ & $35 \%$ \\
\hline $\begin{array}{r}\% \text { w/Persons with } \\
\text { Disabilities }\end{array}$ & $30 \%$ & $30 \%$ & $39 \%$ & $19 \%$ & $20 \%$ \\
\hline$\%$ w/Children & $31 \%$ & $32 \%$ & $33 \%$ & $34 \%$ & $22 \%$ \\
\hline \multicolumn{6}{|l|}{ Household Status } \\
\hline$\%$ Homeowner & $71 \%$ & $86 \%$ & $90 \%$ & $19 \%$ & $2.3 \%$ \\
\hline Mean Household Size & 2.35 & 2.47 & 2.26 & 2.40 & 1.82 \\
\hline$\%$ Single Parent & $22 \%$ & $21 \%$ & $21 \%$ & $34 \%$ & $26 \%$ \\
\hline$\%$ Single Elderly & $30 \%$ & $31 \%$ & $30 \%$ & $21 \%$ & $32 \%$ \\
\hline \multicolumn{6}{|l|}{ Race/Ethnicity } \\
\hline$\%$ White non-Hispanic & $61 \%$ & $59 \%$ & $77 \%$ & $48 \%$ & $50 \%$ \\
\hline$\%$ Black non-Hispanic & $28 \%$ & $31 \%$ & $15 \%$ & $31 \%$ & $24 \%$ \\
\hline$\%$ Hispanic & $10 \%$ & $8 \%$ & $7 \%$ & $17 \%$ & $23 \%$ \\
\hline$\%$ Asian & $0.6 \%$ & $0.5 \%$ & $0.1 \%$ & $1.9 \%$ & $1.7 \%$ \\
\hline$\%$ Native American & $1.4 \%$ & $1.3 \%$ & $1.4 \%$ & $1.4 \%$ & $1.7 \%$ \\
\hline$\%$ Other & $0.2 \%$ & $0.2 \%$ & $0.1 \%$ & $0.0 \%$ & $0.2 \%$ \\
\hline
\end{tabular}

Table 3.3 presents basic statistics about the homes weatherized in PY 2010. As expected, the size of the SF homes is much larger than the MH, SMF and LMF units. The SF homes are also quite a bit older, with $67 \%$ being built prior to 1970 compared to $8 \%, 18 \%$ and $21 \%$ for MH, SMF, and LMF buildings, respectively. Electricity for heating is much more pronounced in MH and LMF buildings. MH are also much more likely to use electricity for supplemental heating and water heating.

Compared to homes weatherized in PY 2008, homes weatherized in PY 2010 are:

- $\quad$ Smaller in size, on average - e.g., the average size of SMF unit in PY 2010 was $800 \mathrm{ft}^{2}$ versus $1,054 \mathrm{ft}^{2}$ in PY 2008

- $\quad$ Newer - e.g., the percent of SF, SMF and LMF built 1970 or later increased from $26 \%$ to $33 \%$, $35 \%$ to $82 \%$ and $49 \%$ to $79 \%$, respectively from PY 2008 to PY 2010.

- $\quad$ Less likely to use bulk fuels - the percent of weatherized SF, MF, SMF and LMF using fuel oil dropped from $14 \%$ to $5 \%, 10 \%$ to $5 \%, 10 \%$ to $3 \%$, and $17 \%$ to $4 \%$, respectively from PY 2008 to PY 2010.

- $\quad$ More likely to use supplemental fuels - e.g., $15 \%$ of SF homes used electricity for supplemental heat in PY 2010 versus 9\% in PY 2008. 
Table 3.2 PY 2010 Clients in Single Family Homes Household Characteristics by Climate Zone

\begin{tabular}{rcccccc} 
Statistic & NATIONAL & Very Cold & Cold & Moderate & Hot/Humid & Hot/Dry \\
\hline Income and Poverty & & & & & & \\
Median Income & 14,400 & $\$ 16,200$ & $\$ 14,200$ & $\$ 13,200$ & $\$ 12,800$ & $\$ 16,000$ \\
High Energy User & $38 \%$ & $39 \%$ & $34 \%$ & $36 \%$ & $50 \%$ & $16 \%$ \\
High Energy Burden & $37 \%$ & $35 \%$ & $25 \%$ & $59 \%$ & $32 \%$ & $26 \%$ \\
\hline $\begin{array}{r}\text { Vulnerability Status } \\
\% \text { w/Elderly Individual }\end{array}$ & $39 \%$ & $35 \%$ & $35 \%$ & $44 \%$ & $47 \%$ & $41 \%$ \\
$\%$ w/Persons with & $30 \%$ & $31 \%$ & $20 \%$ & $39 \%$ & $30 \%$ & $32 \%$ \\
Disabilities & & & & & \\
\% w/Children & $31 \%$ & $38 \%$ & $25 \%$ & $31 \%$ & $31 \%$ & $40 \%$ \\
$\%$ Homeowner & $71 \%$ & $71 \%$ & $68 \%$ & $79 \%$ & $85 \%$ & $50 \%$ \\
\% Single Parent & $22 \%$ & $18 \%$ & $23 \%$ & $18 \%$ & $32 \%$ & $17 \%$ \\
$\%$ Single Elderly & $30 \%$ & $28 \%$ & $27 \%$ & $33 \%$ & $37 \%$ & $33 \%$ \\
\hline Household Status & & & & & & \\
$\%$ White non-Hispanic & $61 \%$ & $84 \%$ & $72 \%$ & $63 \%$ & $28 \%$ & $53 \%$ \\
$\%$ Black non-Hispanic & $28 \%$ & $7 \%$ & $19 \%$ & $28 \%$ & $56 \%$ & $5 \%$ \\
$\%$ Hispanic & $10 \%$ & $5 \%$ & $8 \%$ & $6 \%$ & $15 \%$ & $37 \%$ \\
$\%$ Asian & $0.6 \%$ & $0.2 \%$ & $1 \%$ & $0.4 \%$ & $0.5 \%$ & $1 \%$ \\
$\%$ Other & $1.4 \%$ & $4 \%$ & $0.4 \%$ & $2 \%$ & $0.2 \%$ & $3 \%$ \\
\% Native American & $0.2 \%$ & $0.3 \%$ & $0.1 \%$ & $0.1 \%$ & $0.3 \%$ & $0.0 \%$ \\
\hline Race/Ethnicity & & & &
\end{tabular}

As noted in Table 2.1, both the number and percentage of all homes weatherized increased in the LMF category from PY 2008 to PY 2010. This increase in LMF changed the overall characteristics of homes weatherized in this category. For example, the percentage of buildings using boilers for heat dropped considerably, from 65\% in PY 2008 to 10\% in PY 2010 (Table 3.3). This could be due to more LMF buildings having been weatherized in regions other than Northeast and Midwest in PY 2010. Units were more likely to have supplemental heat in PY 2010 (e.g., 15\% used electricity in PY 2010 versus 5\% in PY 2008) and have central versus window/unit air conditioning (AC) (e.g., 56\% central AC versus $13 \%$ and $12 \%$ window/wall AC versus $73 \%$ ).

Table 3.4 describes units weatherized across climate zones. The units are smaller in the hotter climates and are substantially newer, more likely to have AC, and more likely to heat water with electrical systems. The older homes located in the very cold and cold climate zones are more likely to heat with boilers and use fuel oil. 
Table 3.3 PY 2010 Clients Housing Unit Characteristics by Building Type

\begin{tabular}{|c|c|c|c|c|}
\hline Statistic & Single Family & Mobile Home & $\begin{array}{c}\text { Small } \\
\text { Multifamily }\end{array}$ & $\begin{array}{c}\text { Large } \\
\text { Multifamily }\end{array}$ \\
\hline \multicolumn{5}{|l|}{ Housing Unit } \\
\hline Median Heated Space $\left(\mathrm{ft}^{2}\right)$ & 1310 & 980 & 800 & 741 \\
\hline Mean Heated Space $\left(\mathrm{ft}^{2}\right)$ & 1430 & 1080 & 966 & 771 \\
\hline \multicolumn{5}{|l|}{ Housing Vintage } \\
\hline$\%$ Pre-1940 & $26 \%$ & $1 \%$ & $11 \%$ & $0 \%$ \\
\hline$\%$ 1940-1969 & $41 \%$ & $7 \%$ & $7 \%$ & $21 \%$ \\
\hline$\% 1970$ or Later & $33 \%$ & $92 \%$ & $82 \%$ & $79 \%$ \\
\hline \multicolumn{5}{|l|}{ Heating Fuel } \\
\hline$\%$ Natural Gas & $68 \%$ & $36 \%$ & $77 \%$ & $57 \%$ \\
\hline$\%$ Electric & $22 \%$ & $48 \%$ & $19 \%$ & $38 \%$ \\
\hline$\%$ Fuel Oil & $5 \%$ & $5 \%$ & $3 \%$ & $4 \%$ \\
\hline$\%$ Propane & $4 \%$ & $9 \%$ & $1 \%$ & $1 \%$ \\
\hline$\%$ Other & $1 \%$ & $2 \%$ & $0 \%$ & $0 \%$ \\
\hline \multicolumn{5}{|l|}{ Heating System Type } \\
\hline$\%$ Central Forced Air & $72 \%$ & $84 \%$ & $67 \%$ & $51 \%$ \\
\hline$\%$ Boiler (hydronic/steam) & $9 \%$ & $0 \%$ & $6 \%$ & $10 \%$ \\
\hline$\%$ Wall/Room Heater & $9 \%$ & $6 \%$ & $11 \%$ & $15 \%$ \\
\hline$\%$ Electric Baseboard & $3 \%$ & $1 \%$ & $10 \%$ & $13 \%$ \\
\hline$\%$ Heat Pump & $6 \%$ & $8 \%$ & $5 \%$ & $10 \%$ \\
\hline$\%$ Portable Heater & $1 \%$ & $1 \%$ & $1 \%$ & $>0.0$ \\
\hline$\%$ Other/None & $0 \%$ & $0 \%$ & $0 \%$ & $0 \%$ \\
\hline \multicolumn{5}{|l|}{ Supplemental Heat } \\
\hline$\%$ Electric & $15 \%$ & $21 \%$ & $11 \%$ & $15 \%$ \\
\hline$\%$ Wood & $5 \%$ & $3 \%$ & $1 \%$ & $0 \%$ \\
\hline$\%$ NG/Propane & $13 \%$ & $7 \%$ & $14 \%$ & $10 \%$ \\
\hline \multicolumn{5}{|l|}{ Air Conditioning Type } \\
\hline$\%$ Central AC & $49 \%$ & $48 \%$ & $55 \%$ & $56 \%$ \\
\hline$\%$ Window/Wall & $27 \%$ & $26 \%$ & $18 \%$ & $12 \%$ \\
\hline$\%$ Evaporative Cooler & $6 \%$ & $11 \%$ & $7 \%$ & $1 \%$ \\
\hline \multicolumn{5}{|l|}{ Water Heating Fuel } \\
\hline$\%$ Natural Gas & $62 \%$ & $24 \%$ & $67 \%$ & $63 \%$ \\
\hline$\%$ Electric & $33 \%$ & $71 \%$ & $33 \%$ & $33 \%$ \\
\hline$\%$ Propane & $3 \%$ & $5 \%$ & $0 \%$ & $1 \%$ \\
\hline$\%$ Other & $2 \%$ & $0 \%$ & $0 \%$ & $3 \%$ \\
\hline
\end{tabular}


Table 3.4 PY 2010 Single Family Housing Unit Characteristics by Climate Zone

\begin{tabular}{|c|c|c|c|c|c|}
\hline Statistic & Very Cold & Cold & Moderate & Hot/Humid & Hot/Dry \\
\hline \multicolumn{6}{|l|}{ Housing Unit } \\
\hline Median Heated Space $\left(\mathrm{ft}^{2}\right)$ & 1380 & 1344 & 1289 & 1248 & 1280 \\
\hline Mean Heated Space $\left(\mathrm{ft}^{2}\right)$ & 1480 & 1467 & 1427 & 1343 & 1343 \\
\hline \multicolumn{6}{|l|}{ Housing Vintage } \\
\hline$\%$ Pre-1940 & $40 \%$ & $36 \%$ & $16 \%$ & $5 \%$ & $6 \%$ \\
\hline$\%$ 1940-1969 & $36 \%$ & $42 \%$ & $45 \%$ & $40 \%$ & $33 \%$ \\
\hline$\% 1970$ or Later & $27 \%$ & $22 \%$ & $39 \%$ & $55 \%$ & $61 \%$ \\
\hline \multicolumn{6}{|l|}{ Heating Fuel } \\
\hline$\%$ Natural Gas & $74 \%$ & $83 \%$ & $52 \%$ & $47 \%$ & $81 \%$ \\
\hline$\%$ Electric & $6 \%$ & $7 \%$ & $40 \%$ & $49 \%$ & $15 \%$ \\
\hline$\%$ Fuel Oil & $12 \%$ & $8 \%$ & $2 \%$ & $>0 \%$ & $>0 \%$ \\
\hline$\%$ Propane & $7 \%$ & $2 \%$ & $5 \%$ & $4 \%$ & $3 \%$ \\
\hline$\%$ Other & $2 \%$ & $1 \%$ & $1 \%$ & $>0 \%$ & $1 \%$ \\
\hline \multicolumn{6}{|l|}{ Heating System Type } \\
\hline$\%$ Central Forced Air & $77 \%$ & $80 \%$ & $63 \%$ & $66 \%$ & $65 \%$ \\
\hline$\%$ Boiler (hydronic/steam) & $16 \%$ & $15 \%$ & $3 \%$ & $>0 \%$ & $0 \%$ \\
\hline$\%$ Wall/Room Heater & $3 \%$ & $1 \%$ & $12 \%$ & $21 \%$ & $22 \%$ \\
\hline$\%$ Electric Baseboard & $4 \%$ & $2 \%$ & $4 \%$ & $>0 \%$ & $>0 \%$ \\
\hline$\%$ Heat Pump & $>0 \%$ & $1 \%$ & $16 \%$ & $8 \%$ & $12 \%$ \\
\hline$\%$ Portable Heater & $>0 \%$ & $>0 \%$ & $2 \%$ & $5 \%$ & $1 \%$ \\
\hline$\%$ Other/None & $0 \%$ & $>0 \%$ & $>0 \%$ & $>0 \%$ & $0 \%$ \\
\hline \multicolumn{6}{|l|}{ Supplemental Heat } \\
\hline$\%$ Electric & $12 \%$ & $10 \%$ & $21 \%$ & $21 \%$ & $11 \%$ \\
\hline$\%$ Wood & $14 \%$ & $3 \%$ & $5 \%$ & $2 \%$ & $9 \%$ \\
\hline$\%$ NG/Propane & $5 \%$ & $13 \%$ & $13 \%$ & $16 \%$ & $15 \%$ \\
\hline \multicolumn{6}{|l|}{ Air Conditioning Type } \\
\hline$\%$ Central AC & $17 \%$ & $33 \%$ & $61 \%$ & $61 \%$ & $58 \%$ \\
\hline$\%$ Window/Wall & $28 \%$ & $27 \%$ & $28 \%$ & $32 \%$ & $11 \%$ \\
\hline$\%$ Evaporative Cooler & $3 \%$ & $5 \%$ & $2 \%$ & $4 \%$ & $24 \%$ \\
\hline \multicolumn{6}{|l|}{ Water Heating Fuel } \\
\hline$\%$ Natural Gas & $66 \%$ & $74 \%$ & $45 \%$ & $41 \%$ & $84 \%$ \\
\hline$\%$ Electric & $26 \%$ & $21 \%$ & $52 \%$ & $55 \%$ & $14 \%$ \\
\hline$\%$ Propane & $4 \%$ & $2 \%$ & $3 \%$ & $4 \%$ & $2 \%$ \\
\hline$\%$ Other & $5 \%$ & $3 \%$ & $>0 \%$ & $0 \%$ & $>0 \%$ \\
\hline
\end{tabular}

\subsection{AUDIT APPROACHES AND DIAGNOSTIC PROCEDURES USED}

Table 3.5 describes the audit procedures used by Subgrantees in PY 2008 and PY 2010. There was a drop in the use of priority lists and an increase in the use of computerized audit tools. Overall, though, eightyone percent did not change their audit approach from one period to the next. Table 3.6 indicates little 
change in the roster of most commonly used computerized audit tools: the use of Weatherization Assistant (i.e., NEAT/MHEA) declined slightly and the use of TREAT and EA-QUIP increased slightly.

Table 3.5 Primary measure selection tools used

\begin{tabular}{|l|c|c|c|c|}
\hline Tools used & $\begin{array}{c}\text { Percentage of } \\
\text { subgrantees } \\
\text { PY 2008 }\end{array}$ & $\begin{array}{c}\text { Mean \# of years } \\
\text { used PY 2008 }\end{array}$ & $\begin{array}{c}\text { Percentage of } \\
\text { subgrantees } \\
\text { PY 2010 }\end{array}$ & $\begin{array}{c}\text { Mean \# of years } \\
\text { used PY 2010 }\end{array}$ \\
\hline Priority list & $53 \%$ & 15 & $43 \%$ & 13 \\
\hline $\begin{array}{l}\text { Calculation } \\
\text { procedure }\end{array}$ & $33 \%$ & 11 & $41 \%$ & 12 \\
\hline $\begin{array}{l}\text { Both (for different } \\
\text { units) }\end{array}$ & $12 \%$ & 11 & $4 \%$ & 14 \\
\hline $\begin{array}{l}\text { Ambiguous } \\
\text { responses }\end{array}$ & $2 \%$ & $\mathrm{n} / \mathrm{a}$ & $4 \%$ \\
\hline
\end{tabular}

Table 3.6 Most commonly used calculation procedures

\begin{tabular}{|l|c|c|}
\hline Calculation procedure & $\begin{array}{l}\text { Percentage of subgrantees (of those } \\
\text { who use calculation procedures as a } \\
\text { primary tool) PY 2008 }\end{array}$ & $\begin{array}{l}\text { Percentage of subgrantees (of those } \\
\text { who use calculation procedures as a } \\
\text { primary tool) PY 2010 }\end{array}$ \\
\hline Weatherization Assistant & $53 \%$ & $50 \%$ \\
\hline REM/Rate & $8 \%$ & $6 \%$ \\
\hline TREAT & $7 \%$ & $12 \%$ \\
\hline EA-QUIP & $5 \%$ & $8 \%$ \\
\hline EASY & $5 \%$ & $2 \%$ \\
\hline
\end{tabular}

Table 3.7 describes the diagnostic procedures Subgrantees reported using during the home auditing process. For the most part, the percentages of Subgrantees using each procedure were either about the same from one period to the next or slightly increased. Some of the increases can, in part, be explained by Subgrantees having additional funding for new diagnostic equipment (e.g., use of infrared scanners increased by $14 \%$ and $41 \%$ of Subgrantees reported that ARRA spurred their initial use of this technology). Other increases can be explained by WAP emphasizing certain issues, such as the presence of lead; the percent of Subgrantees that used procedures to detect lead in homes increased by $30 \%$ ). 
Table 3.7 Diagnostic procedures performed by subgrantees in Program Year 2010 and 2008

\begin{tabular}{|c|c|c|}
\hline Diagnostic procedure & $\begin{array}{l}\text { Performed in } \\
\text { PY } 2008\end{array}$ & $\begin{array}{l}\text { Performed in } \\
\text { PY } 2010\end{array}$ \\
\hline Blower door (house air leakage rate) & $98 \%$ & $95 \%$ \\
\hline CO measurements in flues (space heating system) & $93 \%$ & $94 \%$ \\
\hline $\mathrm{CO}$ measurements in flues (water heating system) & $90 \%$ & $90 \%$ \\
\hline Flue gas analysis (space heating system steady-state eff. test) & $86 \%$ & $79 \%$ \\
\hline $\mathrm{CO}$ measurement from cooking stove & $80 \%$ & $85 \%$ \\
\hline Draft/spillage (space heating system, normal operation) & $84 \%$ & $85 \%$ \\
\hline $\mathrm{CO}$ measurements in living areas & $74 \%$ & $79 \%$ \\
\hline Draft/spillage (water heating system, normal operation) & $83 \%$ & $85 \%$ \\
\hline Flue gas analysis (water heating steady-state eff. test) & $72 \%$ & $71 \%$ \\
\hline $\mathrm{CO}$ measurements in equipment rooms & $71 \%$ & $72 \%$ \\
\hline Worst case draft/spillage (CAZ) & $70 \%$ & $79 \%$ \\
\hline Refrigerator energy use & $63 \%$ & $72 \%$ \\
\hline Duct pressure pan measurements & $55 \%$ & $60 \%$ \\
\hline Zonal pressure measurements & $61 \%$ & $66 \%$ \\
\hline Heat rise measurements (space heating system) & $59 \%$ & $55 \%$ \\
\hline Infrared scanning (camera) & $61 \%$ & $75 \%$ \\
\hline Duct Blower & $30 \%$ & $36 \%$ \\
\hline Refrigerant Charge (AC) & $7 \%$ & $9 \%$ \\
\hline Air Handler (AC) & $24 \%$ & $26 \%$ \\
\hline HVAC thermostat current & $32 \%$ & $28 \%$ \\
\hline Flow Rates (Hot water) & $26 \%$ & $32 \%$ \\
\hline Lead & $18 \%$ & $48 \%$ \\
\hline Mold \& Mildew & $9 \%$ & $13 \%$ \\
\hline Exhaust fan flow rate & $31 \%$ & $41 \%$ \\
\hline Moisture & $15 \%$ & $15 \%$ \\
\hline
\end{tabular}

\subsection{MEASURES INSTALLED}

Table 3.8 presents statistics for measures installed in homes weatherized in PY 2010 by building type. Most units across the building types received some sort of air sealing measure (e.g., $89 \%$ for SF homes). Beyond this commonality, variation is present across measures and building types. MHs stand out as particularly different with respect to measures installed. They were the least likely to have attic and wall 
insulation installed. On the other hand, they received substantially more floor and duct insulation, more duct sealing measures, and window measures. The LMF buildings were also treated differently, especially from the typical SF home. They received fewer insulation measures (e.g., only 1\% received duct insulation). It should be noted that the LMF building envelope is much tighter, on average, both pre-and post-weatherization as evidenced by the cubic feet per minute (CFM) rates presented in Table 8.

Over half of the SF and MH received new smoke detectors versus less than a quarter of SMF and LMF homes. It can be hypothesized that owners of rental units (and most WAP recipients living in SMF and LMF are renters) are required to install smoke detectors whereas those living in non-rental units (home ownership is predominant in the SF and MH categories, see Table 3.1) may need assistance in keeping up with the important home safety chore. Over half of the SF, MH and SMF units also needed new carbon monoxide (CO) monitors and even 38\% of the LMF units. This finding could suggest a major public health issue that is being addressed by WAP.

Compared to PY 2008, homes weatherized in PY 2010:

- Had air sealing measures more frequently installed through the guidance of blower doors - e.g., bypass air sealing using blower doors increased from 68\% in SF homes in PY 2008 to 87\% in PY 2010.

- Received fewer insulation measures - e.g., percentages of SF homes receiving attic and wall insulation dropped from $70 \%$ to $65 \%$ and $29 \%$ to $24 \%$ from PY 2008 to PY 2010, respectively and of SMF units from $73 \%$ to $37 \%$ and $44 \%$ to $4 \%$, respectively.

- Received fewer major measures overall - As shown in Table 3.10, the percentage of SF and MF receiving four or more major measures declined from PY 2008 to PY 2010.

Table 3.9 clearly indicates that measures installed varies by climate zone. For example, homes located in the hot and dry climate region are much less likely to receive any type of insulation (e.g., almost $0 \%$ received wall insulation versus $29 \%$ of homes in the cold region) and air sealing measures (possibly because the homes are substantially tighter pre-weatherization). Overall, the homes in the hot and humid climate zone also receive fewer insulation measures than homes in the colder regions. On the other hand, it is interesting that the rate of new heating system installations is not that much lower in the two hot regions than in the colder regions.

In Tables 3.8 and 3.9, it was noted what percentage of energy conservation measures (ECMs) were installed due to the measure passing the SIR test (i.e. windows, new heating systems, new water heating systems, and new air conditioning systems). Oftentimes, the Subgrantees will use their health and safety allowances if the measure fails the SIR test. The percentage of measures that passed the SIR test does vary across measures and climate zones. Although homes receiving window measures was comparatively low (around 20\%), the number of window measures passing the SIR was around $90 \%$ or higher in every climate zone except the cold region. Subgrantees in the cold region, actually, were much more likely to install these types of measures as non-ECM measures than Subgrantees in other regions. On average, new water heaters installations were least likely to pass the SIR test. Table 3.10 indicates that the number of major measures installed in single family and mobile homes declined slightly in PY 2010. 
Table 3.8. PY 2010 Clients Shell Measures by Building Type

\begin{tabular}{|c|c|c|c|c|}
\hline Weatherization Measure & $\begin{array}{l}\text { Single } \\
\text { Family }\end{array}$ & $\begin{array}{l}\text { Mobile } \\
\text { Home }\end{array}$ & $\begin{array}{c}\text { Small } \\
\text { Multifamily }\end{array}$ & $\begin{array}{c}\text { Large } \\
\text { Multifamily }\end{array}$ \\
\hline \multicolumn{5}{|l|}{ Air Sealing } \\
\hline Any Bypass Sealing Or Caulking & $89 \%$ & $90 \%$ & $83 \%$ & $74 \%$ \\
\hline Bypass Sealing w/ Blower Door & $87 \%$ & $87 \%$ & $62 \%$ & $69 \%$ \\
\hline \multicolumn{5}{|l|}{ Attic Insulation } \\
\hline$\%$ Installed (All Types) & $65 \%$ & $23 \%$ & $37 \%$ & $26 \%$ \\
\hline \multicolumn{5}{|l|}{ Wall Insulation } \\
\hline$\%$ Installed (All Types) & $24 \%$ & $3 \%$ & $4 \%$ & $3 \%$ \\
\hline \multicolumn{5}{|l|}{ Other Insulation } \\
\hline$\%$ Floor Insulation & $18 \%$ & $43 \%$ & $2 \%$ & $4 \%$ \\
\hline$\%$ Rim/Band Joist Insulation & $18 \%$ & $1 \%$ & $6 \%$ & $3 \%$ \\
\hline \multicolumn{5}{|l|}{ Windows } \\
\hline Any Window Measure & $18 \%$ & $26 \%$ & $21 \%$ & $17 \%$ \\
\hline New Window (ECM) & $78 \%$ & $80 \%$ & $100 \%$ & $95 \%$ \\
\hline \multicolumn{5}{|l|}{ Air Leakage } \\
\hline CFM Pre & 3130 & 2680 & 1780 & 1370 \\
\hline CFM post & 2290 & 1860 & 1420 & 1120 \\
\hline \multicolumn{5}{|l|}{ Heating Equipment } \\
\hline New Heating System & $30 \%$ & $32 \%$ & $35 \%$ & $34 \%$ \\
\hline New Heating System (ECM) & $66 \%$ & $64 \%$ & $59 \%$ & $62 \%$ \\
\hline \multicolumn{5}{|l|}{ Heating Ducts } \\
\hline Duct Sealing & $36 \%$ & $53 \%$ & $32 \%$ & $33 \%$ \\
\hline Duct Insulation & $11 \%$ & $14 \%$ & $2 \%$ & $1 \%$ \\
\hline New Water Heating Equipment & $14 \%$ & $14 \%$ & $17 \%$ & $9 \%$ \\
\hline New Water Heater (ECM) & $53 \%$ & $49 \%$ & $76 \%$ & $94 \%$ \\
\hline \multicolumn{5}{|l|}{ Ventilation } \\
\hline Whole House, Kitchen, Bath Fan & $21 \%$ & $20 \%$ & $17 \%$ & $10 \%$ \\
\hline \multicolumn{5}{|l|}{ Air Conditioning } \\
\hline New Air Conditioner & $7 \%$ & $10 \%$ & $21 \%$ & $19 \%$ \\
\hline New Air Conditioner (ECM) & $91 \%$ & $85 \%$ & $95 \%$ & $99 \%$ \\
\hline \multicolumn{5}{|l|}{ Other Measures } \\
\hline Refrigerator & $19 \%$ & $23 \%$ & $21 \%$ & $29 \%$ \\
\hline Smoke Alarm & $50 \%$ & $57 \%$ & $22 \%$ & $19 \%$ \\
\hline CO Monitor & $63 \%$ & $58 \%$ & $55 \%$ & $38 \%$ \\
\hline Setback Thermostat & $16 \%$ & $16 \%$ & $15 \%$ & $14 \%$ \\
\hline
\end{tabular}


Table 3.9. PY 2010 Clients Shell Measures by Climate Zone

\begin{tabular}{|c|c|c|c|c|c|}
\hline Weatherization Measure & Very Cold & Cold & Moderate & Hot/Humid & Hot/Dry \\
\hline \multicolumn{6}{|l|}{ Air Sealing } \\
\hline Any Bypass Sealing Or Caulking & $76 \%$ & $94 \%$ & $90 \%$ & $98 \%$ & $75 \%$ \\
\hline Bypass Sealing w/ Blower Door & $91 \%$ & $83 \%$ & $91 \%$ & $90 \%$ & $67 \%$ \\
\hline \multicolumn{6}{|l|}{ Attic Insulation } \\
\hline$\%$ Installed (All Types) & $63 \%$ & $62 \%$ & $56 \%$ & $58 \%$ & $20 \%$ \\
\hline \multicolumn{6}{|l|}{ Wall Insulation } \\
\hline$\%$ Installed (All Types) & $27 \%$ & $29 \%$ & $12 \%$ & $12 \%$ & $>0 \%$ \\
\hline \multicolumn{6}{|l|}{ Other Insulation } \\
\hline$\%$ Floor Insulation & $20 \%$ & $31 \%$ & $32 \%$ & $10 \%$ & $2 \%$ \\
\hline$\%$ Rim/Band Joist Insulation & $25 \%$ & $26 \%$ & $4 \%$ & $1 \%$ & $0 \%$ \\
\hline \multicolumn{6}{|l|}{ Windows } \\
\hline Any Window Measure & $12 \%$ & $23 \%$ & $19 \%$ & $20 \%$ & $19 \%$ \\
\hline New Window (ECM) & $88 \%$ & $47 \%$ & $98 \%$ & $98 \%$ & $90 \%$ \\
\hline \multicolumn{6}{|l|}{ Air Leakage } \\
\hline CFM Pre & 2650 & 3080 & 3360 & 3420 & 2130 \\
\hline CFM post & 1870 & 2240 & 2390 & 2460 & 1840 \\
\hline \multicolumn{6}{|l|}{ Heating Equipment } \\
\hline New Heating System & $35 \%$ & $31 \%$ & $28 \%$ & $27 \%$ & $27 \%$ \\
\hline New Heating System (ECM) & $81 \%$ & $48 \%$ & $65 \%$ & $84 \%$ & $96 \%$ \\
\hline \multicolumn{6}{|l|}{ Heating Ducts } \\
\hline Duct Sealing & $43 \%$ & $36 \%$ & $41 \%$ & $32 \%$ & $52 \%$ \\
\hline Duct Insulation & $6 \%$ & $14 \%$ & $22 \%$ & $9 \%$ & $1 \%$ \\
\hline New Water Heating Equipment & $19 \%$ & $13 \%$ & $8 \%$ & $17 \%$ & $13 \%$ \\
\hline New Water Heater (ECM) & $65 \%$ & $32 \%$ & $46 \%$ & $93 \%$ & $38 \%$ \\
\hline \multicolumn{6}{|l|}{ Ventilation } \\
\hline Whole House, Kitchen, Bath Fan & $22 \%$ & $17 \%$ & $17 \%$ & $41 \%$ & $7 \%$ \\
\hline \multicolumn{6}{|l|}{ Air Conditioning } \\
\hline New Air Conditioner & $1 \%$ & $1 \%$ & $11 \%$ & $18 \%$ & $13 \%$ \\
\hline New Air Conditioner (ECM) & $57 \%$ & $20 \%$ & $95 \%$ & $100 \%$ & $93 \%$ \\
\hline \multicolumn{6}{|l|}{ Other Measures } \\
\hline Refrigerator & $25 \%$ & $20 \%$ & $16 \%$ & $20 \%$ & $17 \%$ \\
\hline Smoke Alarm & $53 \%$ & $35 \%$ & $61 \%$ & $77 \%$ & $27 \%$ \\
\hline CO Monitor & $50 \%$ & $59 \%$ & $69 \%$ & $56 \%$ & $89 \%$ \\
\hline Setback Thermostat & $22 \%$ & $14 \%$ & $12 \%$ & $20 \%$ & $13 \%$ \\
\hline
\end{tabular}


Table 3.10 Number of Major Measures Installed (\%)

\begin{tabular}{|l|c|c|c|c|}
\hline & \multicolumn{2}{|c|}{ Site Built Homes } & \multicolumn{2}{c|}{ Mobile Homes } \\
\hline & $\mathbf{2 0 0 8}$ & $\mathbf{2 0 1 0}$ & $\mathbf{2 0 0 8}$ & $\mathbf{2 0 1 0}$ \\
\hline None & $11 \%$ & $12 \%$ & $14 \%$ & $13 \%$ \\
\hline One & $31 \%$ & $31 \%$ & $29 \%$ & $26 \%$ \\
\hline Two & $31 \%$ & $33 \%$ & $30 \%$ & $32 \%$ \\
\hline Three & $20 \%$ & $18 \%$ & $16 \%$ & $21 \%$ \\
\hline Four or more & $6 \%$ & $5 \%$ & $11 \%$ & $7 \%$ \\
\hline
\end{tabular}

\subsection{CLIENT EDUCATION}

Similar to results presented above, actions associated with and topics surrounding client education were quite similar across the two evaluation time periods. Referring to Table 3.11, Subgrantees reported they provided in-person instruction at the time of the audit most frequently and then again at the time of weatherization and again post-weatherization inspection. Clients were frequently provided consumer energy literature at the point of intake and during the audit. Less than a quarter of Subgrantees scheduled separate client education visits. Overall, agencies implemented between 5 and 6 different types of client education actions, with the mean increasing slightly during the ARRA period.

Table 3.12 presents the topics covered by the Subgrantees as part of their client education actions. Frequent topics of client education include: thermostat management, HVAC system operations/maintenance; insulation, windows and lighting. Most Subgrantees covered over half of the eighteen topics listed in the table. Coverage of topics remained about the same between the two time periods, with Subgrantees increasing coverage on average by less than one topic. Three topics that did receive additional coverage were safety monitors, refrigerators and mold, which increased by $15 \%, 10 \%$, and $9 \%$, respectively.

It should be noted that during both periods, client education was not a WAP reimbursable specific measure; therefore, Subgrantees could only bill their Grantees for client education actions within personnel costs in program operations. In this light, high rates of in-person instruction and the providing of literature that could take place simultaneously with required weatherization processes such as auditing and inspection should be expected as should low rates for actions that require expenditures, such as the provision of CDs/DVDs and hardware kits that could only be charged to training and technical assistance accounts. This may further explain why many of the more complex topics, such as cooling load reduction, were tackled less frequently. 
Table 3.11 Client Education Actions (\%)

\begin{tabular}{|c|c|c|}
\hline Client Education Actions & 2008 & 2010 \\
\hline \multicolumn{3}{|l|}{ Intake } \\
\hline Provide literature at time of client intake & $62 \%$ & $54 \%$ \\
\hline Provide video, CD or DVD at time of client intake & $5 \%$ & $3 \%$ \\
\hline Provide in-person instruction at time of client intake & $42 \%$ & $39 \%$ \\
\hline Provide hardware kit at time of client intake & $5 \%$ & $5 \%$ \\
\hline \multicolumn{3}{|l|}{ Audit } \\
\hline Provide literature at time of audit & $76 \%$ & $80 \%$ \\
\hline Provide video, CD or DVD at time of audit & $3 \%$ & $3 \%$ \\
\hline Provide in-person instruction at time of audit & $84 \%$ & $87 \%$ \\
\hline Provide hardware kit at time of audit & $6 \%$ & $9 \%$ \\
\hline \multicolumn{3}{|l|}{ Weatherization } \\
\hline Provide literature at time of weatherization & $21 \%$ & $22 \%$ \\
\hline Provide video, CD or DVD at time of weatherization & $1 \%$ & $1 \%$ \\
\hline Provide in-person instruction at time of weatherization & $71 \%$ & $76 \%$ \\
\hline Provide hardware kit at time of weatherization & $6 \%$ & $4 \%$ \\
\hline \multicolumn{3}{|l|}{ Special visit } \\
\hline Provide literature at separate client education visit & $20 \%$ & $22 \%$ \\
\hline Provide video, CD or DVD at separate client education visit & $2 \%$ & $4 \%$ \\
\hline Provide in-person instruction at separate client education visit & $23 \%$ & $28 \%$ \\
\hline Provide hardware kit at separate client education visit & $4 \%$ & $8 \%$ \\
\hline \multicolumn{3}{|l|}{ Inspection } \\
\hline Provide literature at time of inspection & $31 \%$ & $34 \%$ \\
\hline Provide video, CD or DVD at time of inspection & $1 \%$ & $1 \%$ \\
\hline Provide in-person instruction at time of inspection & $77 \%$ & $79 \%$ \\
\hline Provide hardware kit at time of inspection & $2 \%$ & $3 \%$ \\
\hline Group training class & $14 \%$ & $13 \%$ \\
\hline Mean \# actions (Std. Deviation) & $5.5(2.49)$ & $5.7(2.62)$ \\
\hline
\end{tabular}


Table 3.12 Client Education Topics (\%)

\begin{tabular}{|c|c|c|}
\hline Client Education Topics & 2008 & 2010 \\
\hline Insulation & $86 \%$ & $86 \%$ \\
\hline Thermostat management & $89 \%$ & $86 \%$ \\
\hline Lighting & $84 \%$ & $84 \%$ \\
\hline Safety monitors (e.g., CO monitors, smoke alarm) & $69 \%$ & $84 \%$ \\
\hline HVAC system operation/maintenance & $77 \%$ & $82 \%$ \\
\hline Ventilation & $75 \%$ & $77 \%$ \\
\hline Mold & 665 & $75 \%$ \\
\hline Hot water use & $74 \%$ & $74 \%$ \\
\hline Refrigerator & $63 \%$ & $73 \%$ \\
\hline Windows & $75 \%$ & $68 \%$ \\
\hline Energy bills & $58 \%$ & $63 \%$ \\
\hline Water heating system operation/maintenance & $59 \%$ & $62 \%$ \\
\hline Other baseload electric use & $48 \%$ & $56 \%$ \\
\hline Laundry & $45 \%$ & $47 \%$ \\
\hline Kitchen appliance operation & $41 \%$ & $43 \%$ \\
\hline Energy Star & $42 \%$ & $42 \%$ \\
\hline Distribution system adjustment and zoning & $33 \%$ & $29 \%$ \\
\hline Cooling load reduction & $23 \%$ & $24 \%$ \\
\hline Mean \# actions (Std. Deviation) & $11.1(4.25)$ & $11.6(4.56)$ \\
\hline
\end{tabular}

\subsection{TRAINING}

The training venues used by Subgrantees changed little between the time periods. The National Weatherization Program Conference continued to be a popularly attended, though a bit less than a State's weatherization conference (see Table 3.13). Overall, training that may have required out-of-state travel declined somewhat during the ARRA period. In contrast, local classes and webcasts provided by the Subgrantees themselves, increased. One could argue that due to production pressures during the ARRA period more time efficient training methods were preferred, on balance.

In general, the Subgrantees' assessments of training quality by venue were about the same from one period to the next. However, average scores by topic were slightly lower during the ARRA period across the board (see Table 3.14). 
Table 3.13 Training venues used by subgrantees

\begin{tabular}{|l|c|c|}
\hline Training Venue & PY 2008 & PY 2010 \\
\hline National Weatherization Program Conference & $45 \%$ & $29 \%$ \\
\hline Affordable Comfort Conference & $35 \%$ & $8 \%$ \\
\hline Other national conference & $13 \%$ & $26 \%$ \\
\hline Regional weatherization conference & $32 \%$ & $50 \%$ \\
\hline State's weatherization conference & $51 \%$ & $17 \%$ \\
\hline Other in-state conference & $26 \%$ & $3 \%$ \\
\hline Weatherization conference in another state & $5 \%$ & $4 \%$ \\
\hline Other conference given in another state & $4 \%$ & $43 \%$ \\
\hline State or regional training center class & $40 \%$ & $13 \%$ \\
\hline Manufacturer's training school class & $11 \%$ & $13 \%$ \\
\hline Utility training class & $14 \%$ & $45 \%$ \\
\hline Training class provided by responding agency & $29 \%$ & $28 \%$ \\
\hline One-time state-sponsored class & $19 \%$ & $11 \%$ \\
\hline Other external class & $8 \%$ & $13 \%$ \\
\hline Visit to another agency & $20 \%$ & $33 \%$ \\
\hline State instruction to responding agency & $28 \%$ & $29 \%$ \\
\hline In-person expert visit & $26 \%$ & $30 \%$ \\
\hline Webcast & $8 \%$ & $2 \%$ \\
\hline
\end{tabular}


Table 3.14 Training quality by venue - subgrantee assessment

\begin{tabular}{|c|c|c|c|c|}
\hline Training Venue & $\begin{array}{l}\text { Overall } \\
\text { training } \\
\text { quality } \\
\text { PY } 2008\end{array}$ & $\begin{array}{l}\text { Top-rated topics } \\
\text { PY 2008* }\end{array}$ & $\begin{array}{l}\text { Overall } \\
\text { training } \\
\text { quality } \\
\text { PY } 2010\end{array}$ & $\begin{array}{l}\text { Top-rated topics } \\
\text { PY 2010* }\end{array}$ \\
\hline $\begin{array}{l}\text { State/Regional } \\
\text { Training Center }\end{array}$ & High & $\begin{array}{l}\text { Outreach (4.17) } \\
\text { Health \& safety }(4.27) \\
\text { Wx methods }(4.26)\end{array}$ & High & $\begin{array}{l}\text { Auditing (3.89) } \\
\text { Diagnostics (3.97) } \\
\text { Wx methods (3.97) }\end{array}$ \\
\hline $\begin{array}{l}\text { Internal Training } \\
\text { (e.g., by own state) }\end{array}$ & High & $\begin{array}{l}\text { Client education (4.40) } \\
\text { Diagnostics (4.09) } \\
\text { Wx methods (4.11) }\end{array}$ & High & $\begin{array}{l}\text { Auditing (4.06) } \\
\text { Measure selection (4.06) } \\
\text { Wx methods (4.12) }\end{array}$ \\
\hline $\begin{array}{l}\text { Affordable Comfort } \\
\text { Conference }\end{array}$ & Medium-high & $\begin{array}{l}\text { Health \& safety (3.68) } \\
\text { Wx methods }(3.72)\end{array}$ & Medium-high & $\begin{array}{l}\text { Diagnostics (3.60) } \\
\text { Wx Methods (3.51) }\end{array}$ \\
\hline $\begin{array}{l}\text { National } \\
\text { Weatherization } \\
\text { Program Conference }\end{array}$ & Medium-high & $\begin{array}{l}\text { Auditing (3.72) } \\
\text { Health \& safety (3.69) }\end{array}$ & Medium-high & $\begin{array}{l}\text { Diagnostics (3.54) } \\
\text { Wx Methods (3.59) }\end{array}$ \\
\hline $\begin{array}{l}\text { Regional } \\
\text { Weatherization } \\
\text { Conference }\end{array}$ & Medium-high & $\begin{array}{l}\text { Outreach (3.89) } \\
\text { Health \& safety (3.88) } \\
\text { Wx methods (3.92) }\end{array}$ & Medium-high & $\begin{array}{l}\text { Diagnostics }(3.70) \\
\text { Measure selection }(3.60) \\
\text { Wx methods }(3.67)\end{array}$ \\
\hline $\begin{array}{l}\text { State Weatherization } \\
\text { Conference }\end{array}$ & Medium-high & Diagnostics (3.71) & Medium-high & Diagnostics (3.60) \\
\hline
\end{tabular}

$* 1=$ very low, $2=$ low, $3=$ medium, $4=$ high, $5=$ very high.

Certification requirements for auditors increased somewhat from the retrospective period to the ARRA period; $73 \%$ of Subgrantees reported requiring certification in the former period versus $80 \%$ in the latter. Other requirements for auditors, such as: "some weatherization experience", "some experience in supervising weatherization work" and "some experience in construction", were basically unchanged at $64 \%$ to $61 \%, 31 \%$ to $36 \%$, and $55 \%$ to $60 \%$, respectively. In PY 2010, $81 \%$ of Subgrantees had in-house certification for inspection but only $25 \%$ required certification for contractors. Also, $50 \%$ of Subgrantees had in-house crew certification for installation and 53\% required certification for contractor installers.

\subsection{LARGE MULTIFAMILY BUILDINGS}

DOE and others make a distinction between small and large multifamily buildings. The former contain between 2-4 units and the latter 5+ units. Units in most small multifamily buildings are individually heated and cooled and have their own hot water systems. From a building science point of view, these units behave very similarly to single family homes, thus allowing Subgrantees to use similar audit tools and diagnostic procedures (such as blower doors), and install similar measures.

Large multifamily buildings are different in several ways. First, a significant number have central heating and hot water systems. It ranges from difficult to near impossible to install insulation in individual units. 
The buildings are too large for most common diagnostic procedures (again, such as blower doors) to provide meaningful insights. These buildings also consume energy in a variety of common spaces. Thus, special large multifamily auditing procedures are needed as are weatherization work procedures. For example, replacing a central boiler in a 240 unit large multifamily building in New York City actually requires a heavy construction or engineering plan, especially if the old boiler needs to be cut into pieces before it can be removed from the boiler room.

Because a large portion of low-income households live in large multifamily buildings, weatherization of this building stock was a point of emphasis during the Recovery Act period. DOE encouraged Grantees to allow and assist their Subgrantees to weatherize multifamily buildings. Additionally, DOE entered into agreements to allow the weatherization of public-assisted housing and U.S. Department of Housing and Urban Development (HUD) assisted properties on an eligibility list without having to verify individual household eligibility at the unit level. This shift resulted in $88 \%$ of Subgrantees tackling weatherization of large multifamily buildings, public housing, and HUD assisted properties during PY 2010. Amongst these weatherized units, $60 \%$ were found in privately owned large multifamily buildings, $15 \%$ in publicassisted housing, and 25\% in HUD assisted housing. Three quarters of the Subgrantees reported that the total number of units in weatherized large multifamily buildings in PY 2010 was less than 1000, 18\% reported the number of units ranged between 1000 and 5000, and 8\% reported weatherizing more than 5000 units.

The percentage of Subgrantees that actually weatherized large multifamily buildings in PY 2010 is below the percentage that were allowed to do so: $49 \%$ reported weatherizing privately owned large multifamily buildings, 63\% public-assisted housing, and 44\% HUD assisted buildings. These Subgrantees reported weatherizing on average 153, 72, and 122 units in privately owned, public-assisted housing, and HUD assisted large multifamily buildings, respectively.

The national weatherization network has vocalized that numerous barriers to weatherizing large multifamily buildings exist. Table 3.15 presents these barriers as well as the percentages of Grantees and Subgrantees that reported perceiving each barrier as real. Generally, most agree that there are simply too few large multifamily buildings located within their territory to weatherize. Beyond this, the Grantees and Subgrantees have quite different perceptions, with the former perceiving many more barriers than the latter.

Table 3.15 Barriers to Weatherizing Large Multifamily Buildings (\%)

\begin{tabular}{|l|c|c|}
\hline Barriers & Grantees & Subgrantees \\
\hline Few LMF buildings present & $39 \%$ & $42 \%$ \\
\hline LMF building owners are uncooperative & $27 \%$ & $25 \%$ \\
\hline Lack of LMF building auditors & $55 \%$ & $18 \%$ \\
\hline Unclear owner contributions & $34 \%$ & $16 \%$ \\
\hline Energy savings are not high enough & $11 \%$ & $15 \%$ \\
\hline Too expensive to weatherize LMF buildings & $34 \%$ & $14 \%$ \\
\hline Lack of LMF weatherization crews & $27 \%$ & $10 \%$ \\
\hline
\end{tabular}




\subsection{OTHER MISCELLANEOUS TOPICS}

This subsection addresses several WAP-related issues not previously discussed: wait lists, marketing approaches, deferrals, historic preservation guidelines and renewable portfolio standards.

In PY 2008, approximately 35 million homes were income eligible for weatherization services. DOE funding for PY 2008 contributed to weatherizing approximately 100,000 units. This resulted in lengthy waiting lists for weatherization. Indeed, in PY 2008, the mean number of homes on the Subgrantees' waiting list was 642 and the number of days a home waited for services was 323. One might have expected that the substantial increase in production during the Recovery Act would have reduced these numbers appreciably but that was not the case, at least by PY 2010. The mean number of homes on the wait list was 544 and the number of days on the list was 211 . The increased attention given to the program in the media, it could be argued, prompted more applications to the program than usual as well as the increase in qualifying income limits.

Table 3.16 describes the approaches used by Subgrantees to market their weatherization programs in PYs 2008 and 2010. Most Subgrantees utilized passive marketing approaches, such as mailings to clients, ads and their website. Possibly because of their long waiting lists and costs, few undertook more aggressive marketing approaches, such as radio and TV. As seen above, marketing approaches in PY 2010 were similar to those used in PY 2008. The mean number of approaches used by Subgrantees was the same at about three. Only about 1-2\% of Subgrantees employed 8 or 9 of the approaches listed in Table 3.16. Between 8 and 14\% did no marketing at all. One point worth noting here is that Subgrantees increased visits to clients and property owners in PY 2010, the latter possibly a reaction to DOE emphasizing the need to weatherize more large multifamily buildings.

Table 3.16 Approaches Used by Subgrantees to Market WAP (\%)

\begin{tabular}{|l|c|c|}
\hline Marketing Approach & $\mathbf{2 0 0 8}$ & $\mathbf{2 0 1 0}$ \\
\hline Mailings to Clients & $41 \%$ & $39 \%$ \\
\hline Mailings to Property Owners & $14 \%$ & $18 \%$ \\
\hline Visits to Clients & $20 \%$ & $27 \%$ \\
\hline Visits to Property Owners & $12 \%$ & $20 \%$ \\
\hline Ads with Other Social Services & $64 \%$ & $56 \%$ \\
\hline Newspapers/Magazines & $42 \%$ & $48 \%$ \\
\hline Radio & $18 \%$ & $22 \%$ \\
\hline TV & $12 \%$ & $14 \%$ \\
\hline Website & $64 \%$ & $60 \%$ \\
\hline Mean Number of Marketing Approaches & $\mathbf{2 . 9}$ & $\mathbf{3 . 0}$ \\
\hline
\end{tabular}

There are times when Subgrantees defer weatherization services for a home. This happens when, for instance, the home's poor structural condition would render weatherization ineffective (and WAP funds cannot be utilized for extensive home repairs) or when conditions in the home may pose health and safety risks to staff or occupants. Deferral is an important issue for DOE and the national weatherization community because these homes tend to be those in the greatest disrepair resulting in the occupants being in greater need. All grantee respondents reported having a state-level deferral policy in 2010 and a further $83 \%$ of Subgrantees also reported having a specific deferral policy. The Recovery Act evaluation 
produced a very in-depth report on the topic. ${ }^{14}$ Tables 3.17 and 3.18 present a few descriptive statistics about deferrals to provide some context.

Table 3.17 suggests that most Grantees and Subgrantees reported deferring at least some units for weatherization in PY 2010. Discussions with Subgrantees in the national weatherization network suggest that those with the highest deferral rate service urban centers in the cold and very cold climate zones. One might have expected deferral rates to decrease during the ARRA period because of the unprecedented production expectations. The results presented in Table 3.18 do not support this supposition, as $40 \%$ of Subgrantees reported higher deferral rates. When a unit is deferred, often it is up to the potential client to find the resources to rectify the condition prompting the deferral as ; however, as one would expect this could be a difficult task for most clients. Table 3.19 presents the low percentage of homes that reentered the weatherization queue post-deferral.

Subgrantees were asked this question: What would be the ideal amount of money per home your agency would like to spend for addressing health and safety issues? The mean answer was $\$ 2800$. This masks a range from $\$ 0$ to $\$ 25000$, a median of $\$ 2000$, and a standard deviation of $\$ 2660$. A handful of agencies feel strongly that health and safety expenditures need to be expanded greatly whereas the majority believes the current program has the level just about right.

Table 3.17 Units deferred in $2010(\%)$

\begin{tabular}{|l|c|c|}
\hline$\%$ of units deferred & Grantee & Subgrantee \\
\hline $\mathbf{0 \%}$ & $2 \%$ & $15 \%$ \\
\hline $\mathbf{1 - 5 \%}$ & $55 \%$ & $48 \%$ \\
\hline $\mathbf{6 - 1 0 \%}$ & $23 \%$ & $17 \%$ \\
\hline $\mathbf{1 0 - 2 0 \%}$ & $16 \%$ & $10 \%$ \\
\hline $\mathbf{2 1 - 3 0 \%}$ & $2 \%$ & $6 \%$ \\
\hline More than $\mathbf{3 0 \%}$ & $2 \%$ & $4 \%$ \\
\hline
\end{tabular}

Table 3.18 PY 2010 deferral rate vs PY $2008(\%)$

\begin{tabular}{|l|c|c|}
\hline & Grantee & Subgrantee \\
\hline Very great decrease & $0 \%$ & $>0$ \\
\hline Great decrease & $0 \%$ & $1 \%$ \\
\hline Decrease & $2 \%$ & $4 \%$ \\
\hline No change & $65 \%$ & $53 \%$ \\
\hline Increase & $29 \%$ & $33 \%$ \\
\hline Great increase & $4 \%$ & $7 \%$ \\
\hline Very great increase & $0 \%$ & $2 \%$ \\
\hline
\end{tabular}

\footnotetext{
${ }^{14}$ See Rose et.al. (2014). Exploratory Review of State, Agency and Client Experiences with Deferred Services Under the Weatherization Assistance Program.
} 
Table 3.19 Previously deferred units slated to be weatherized PY 2010 (\%)

\begin{tabular}{|l|c|c|}
\hline Percent & Grantee & Subgrantee \\
\hline $\mathbf{0 \%}$ & $6 \%$ & $27 \%$ \\
\hline $\mathbf{1 - 2 5 \%}$ & $78 \%$ & $58 \%$ \\
\hline $\mathbf{2 6 - 5 0 \%}$ & $14 \%$ & $6 \%$ \\
\hline $\mathbf{5 1 - 7 5 \%}$ & $0 \%$ & $3 \%$ \\
\hline $\mathbf{7 6 - 9 0 \%}$ & $2 \%$ & $2 \%$ \\
\hline $\mathbf{9 1 - 1 0 0 \%}$ & $0 \%$ & $4 \%$ \\
\hline
\end{tabular}

There is a flip side to the deferral issue. Some homes that are in good condition may not be weatherized or may have weatherization delayed or altered because of State Historic Preservation Office (SHPO) restrictions. Generally, states have programs to preserve and protect historic buildings. Weatherization of homes that are on the federal register or otherwise designated for preservation requires approvals and special consideration. In most cases where weatherization does not impact the exterior of the home, weatherization can proceed straightforwardly. However, all older homes need to be researched beforehand to identify those that need pre-approvals for weatherization. This turned out to be a major new issue faced by Grantees in the Recovery Act period: $96 \%$ reported that their states had SHPO agreements and $26 \%$ indicated that $11 \%$ or more of their prospective units were covered by SHPO agreements. Seventy-five percent of the Subgrantees work under SHPO agreements and 19\% have 11\% or more units falling under the agreements. Seventeen percent indicated that the SHPO guidelines changed the types of measures installed.

Lastly, Grantees were asked whether state renewable portfolio standards (RPS) benefit their weatherization programs. RPS set goals for what percentage of electricity needs to be produced by renewable energy sources by a certain date. Many states include energy efficiency within their RPS programs. If energy efficiency is included, then utilities in that state would be more motivated to invest in energy efficiency, including weatherization. For the weatherization community it is a hopeful sign that almost one-third of the Grantees (31\%) reported that their state's RPS does benefit their program. 



\section{CONCLUSIONS}

In summary, the Recovery Act was a unique period in the history of WAP. Funding reached unprecedented levels. The media attention on and oversight of WAP was also unprecedented. The national network ramped up its workforce and met its production goals. Survey results suggest that the Grantees' experiences of the Recovery Act were more negative than the experiences of the Subgrantees, but overall, the network seems to have judged that the Recovery Act was, on balance, a positive for lowincome weatherization in the United States.

Other than the sheer number of units weatherized during PY 2010, the program as administered in PY 2010 was very similar to the program administered in PY 2008. Overall, there were no substantive changes in audit tools used, measures installed, training offered and taken, and client education practices. The characteristics of the recipients and their homes changed somewhat, due to a combination of an increase in the income eligibility threshold (from $150 \%$ to $200 \%$ of poverty) and a larger percentage of weatherized homes falling into the hot climate regions. 



\section{REFERENCES}

Bensch, I., Keene, A., Cowan, C., and Koski, K. 2014. National Weatherization Assistance Program Characterization: Describing the Pre-ARRA Program. ORNL/TM-2013/188, Oak Ridge National Laboratory, Oak Ridge, Tennessee, April.

Rose, E., Hawkins, B., Tonn, B., Ashcraft, L., and Miller, C. 2014. Exploratory Review of State, Agency and Client Experiences with Deferred Services Under the Weatherization Assistance Program. ORNL/TM-2014/364 Oak Ridge National Laboratory, Oak Ridge, TN, September.

Tonn, B., Rose, E., and Hawkins, B. 2014. Weatherization Beyond the Numbers: Case Studies of Fifteen High-Performing Weatherization Agencies - Conducted May 2011 - July 2012. ORNL/TM-2014/317, Oak Ridge National Laboratory, Oak Ridge, Tennessee, September.

Tonn et al. 2011. Evaluation of the National Weatherization Assistance Program During Program Years 2009-2011 (American Recovery and Reinvestment Act Period). ORNL/TM-2011/87, Oak Ridge National Laboratory, Oak Ridge, TN, December. 



\section{APPENDIX - RESEARCH APPROACH}

\section{A.1 SURVEY INSTRUMENTS AND DATA FORMS}

This subsection briefly describes the five main information collection instruments used to develop the results presented in this report. ${ }^{15}$

- S1 - All States Program Information Survey. Every WAP grantee was asked to complete this survey. Questions that specifically pertained to the operation of their weatherization programs in PY 2010 focused on program outputs (e.g., number of units weatherized by housing type), expenditures and leveraging, grantee program staffing and training, and quality assurance monitoring. Questions that pertained to the grantees experiences during the ARRA period focused on changes to state-level weatherization network, media coverage, and Davis Bacon.

- S2 - All Agencies Program Information Survey. Similar to the grantee survey, every WAP subgrantee was asked to complete this survey. Questions that specifically pertained to the operation of their weatherization programs in PY 2010 focused on program outputs (e.g., number of units weatherized by housing type), expenditures and leveraging, subgrantee program staffing and training, and quality assurance monitoring. Questions that pertained to the subgrantees experiences during the ARRA period focused on changes to state-level weatherization network, media coverage, and Davis Bacon.

- S3 - Sampled of Agencies Detailed Program Information Survey. A sample of 450 subgrantees was selected to complete this survey (details on the selection process are presented below). Questions focused on agency operations and outcomes on PY2010, including audit and home diagnostic processes, client education, training and certification requirements for staff, and inspection practices.

- DF2/3 - Housing Unit/Building Information Survey. The sampled subgrantees were asked to provide information for a sample of housing units (DF2) and multifamily buildings (DF3) weatherized in PY2010 (details on this sampling procedure are also discussed below). This data form collected very detailed information on measures installed, job costs, and some additional characteristics about the home and household for several thousand homes.

- $\quad \mathrm{DF} 4 \mathrm{a} / \mathrm{b}$ - Electric \& Natural Gas Information From Agencies Data Form. The sampled subgrantees were asked to provide primary heating fuel and number of units in each home/building weatherized in PY2010 and PY2011 (the latter is used as the comparison group) (DF4a). From this list, specified numbers of homes and buildings were sampled to be included in the billing analyses. The lists were sent back to the subgrantees, who then provided information to allow the evaluation team to contact the requisite utilities and collect the billing histories (DF4b).

It should be noted that the Office of Management and Budget (OMB) reviewed each of these information collection instruments, data collection and sampling approaches, and estimated burden to be placed on the various respondents. According to OMB guidelines, the public was also provided a period of time to comment on the proposed information collection request. The OMB control number assigned to the WAP ARRA period evaluation information collection request is 1910-5168.

\footnotetext{
${ }^{15}$ Survey instruments (marked with an ' $\mathrm{S}$ ' in their shortened names) addressed quantitative and qualitative information about program operations and administration at an aggregate level; data forms (marked with a 'DF') collected detailed information about specific weatherized units or subgrantees.
} 


\section{A.2 SAMPLING FRAME AND DATA}

As described above, S3, DF2/3 and DF4a/b were administered to a sample of subgrantees. The sample of subgrantees was developed to meet the needs of the energy savings analyses. The same sample was used for the survey and data forms. This subsection describes the approach used to sample the subgrantees and also to sample weatherization jobs to collect the measures installed data.

For the retrospective evaluation, the sample size of 400 agencies and 10,000 housing units was selected so that the nationwide total annual energy savings (and average energy savings per housing unit) attributable to the Program can be estimated to within $\sim 15 \%$ of its actual value at a $90 \%$ confidence level after nonresponse and attrition are taken into account. Agencies (and thus their housing units) were sampled rather than sampling housing units directly from among all agencies nationwide because of the cost that would be involved in working cooperatively with 900 separate agencies. The 400 agencies were selected in two steps: the number of agencies to be selected from each state was determined first, and then agencies within each state were selected.

The selection of the 400 agencies was stratified by state because such stratification:

- controls for differences in geography, climate, housing stock, fuel types, and other factors;

- controls for the fact that each state administers its program differently (i.e., savings for homes or agencies are likely to be similar to other homes or agencies in the same state rather than a different state);

- ensures that each state will have at least one agency included in the sample; and

- ensures that data provided by states that wish to contribute resources to extend the survey in their states can be easily incorporated into the analysis, and the benefit to the state from doing so can be clearly seen. ${ }^{16}$

The number of individual agencies that were originally selected from each state were in proportion to the amount (or "size") of the weatherization activity that occurred in each state in PY 2008. For the retrospective evaluation, "size" was defined as the amount of DOE Program funding received by the state. If, for example, a state received 5 percent of the Program's available funding, then 20 agencies (5 percent of 400) would be selected from that state. The number of agencies counted in a state was rounded up to 2 even if its numerical proportion was 1.5 or less in order to ensure that an agency from each state was included in the sample, that standard deviations could be calculated for each state, and that the 14 hotclimate states were adequately represented. It should be stressed that neither the retrospective nor the WAP ARRA period evaluations are interested in comparing states, but that the method of stratification by states is being used to improve the sampling randomization and to minimize the sampling error.

Agencies were selected within a state using probability proportional to size (PPS) sampling, with "size" again defined as the amount of DOE Program funding received by the agency from ARRA funds. PPS sampling is a standard statistical method that selected agencies that were representative of the entire state but which preferentially selects larger agencies (i.e., agencies that received more DOE Program funding) with a higher probability than smaller agencies. This sampling approach led to estimates of totals that are more accurate than estimates based on simple random sampling (i.e., equal probability sampling).

The agency sampling for this WAP ARRA period evaluation differed from the agency sampling approach for the retrospective study for three reasons. First, there were 129 more agencies providing weatherization

\footnotetext{
${ }^{16}$ To date, only a few states have piggybacked state-level evaluations on the national evaluations.
} 
services during the ARRA period than during the retrospective period. The sampling approach needed to include some new agencies in the sub-sample.

Second, an important component of this evaluation is an assessment of the outcomes of the Sustainable Energy Resources for Consumers Program (SERC), initiated during the ARRA period. ${ }^{17}$ This program awarded grants to 92 local weatherization agencies to install renewable energy and advanced energy efficiency measures. For reasons explained in ARRA period evaluation plan, it is necessary to collect billing histories for the SERC homes for all 92 agencies. Thus, all 92 agencies need to be part of the subsample. Of these 92 agencies, 35 were in the original sample of 400, 50 were not, and 5 were new to the program. ${ }^{18}$

Third, experiences gained during the data collection phase of the retrospective evaluation suggest that some of the subsampled agencies cannot be persuaded to participate in this project. On the other hand, the identities of very willing agency participants are known. Thus, the revised methodology incorporates known respondents and drops known non-respondents from the set of sub-sample agencies. It should be noted that it is important to ensure that the WAP ARRA period sub-sample of agencies includes a substantial number of agency respondents for the retrospective evaluation in order to facilitate comparisons across a large number of variables between the two time periods.

Combining these factors together yields the following approach to developing the set of sub-sampled agencies:

- The 344 agencies that responded during the retrospective study were included in the sub-sample (344 out of 847 equals $41 \%$ of the original set of retrospective agencies);

- Included in this set of 344 agencies are 35 agencies that received SERC grants;

- Fifty-six new agencies were included in the sample (56 out of 129 new agencies equals $43 \%$ of the new agencies);

- All five of the new agencies that also received SERC grants were included in the set of 56 new agencies;

- The other 50 agencies that received SERC grants but were not part of the retrospective subsample of agencies were also included in the new set of sub-sampled agencies; and

- The sample size for the sub-sampled agencies for the WAP ARRA period evaluation increased to 450 for this reason.

Thus, 450 subgrantees were approached to complete $\mathrm{S} 3, \mathrm{DF} 2 / 3$ and $\mathrm{DF} 4 \mathrm{a} / \mathrm{b}$.

In general, $33 \%$ of the housing units and buildings whose primary heating fuel is natural gas or electricity and that were weatherized by each agency were randomly selected for inclusion in the ARRA period evaluation sample. Thus, with respect to this program characterization report, the evaluation team endeavored to collect DF2/3 and DF4a/b data forms for this sample of homes weatherized in PY2010. Additionally, subgrantees were asked to provide these data on $25 \%$ of homes weatherized that heat with bulk fuels (i.e., fuel oil, propane). At least seven housing units were selected from each agency to ensure that three housing units remain for each agency after non-response and attrition are considered.

To reduce the burden on agencies with respect to responding to the DF2/3 data collection request, two new versions of the data forms were developed. Using the original DF2/3 forms as the basis, a short version was developed that reduced the number of data items by approximately $50 \%$. Then, an Easy

\footnotetext{
${ }^{17}$ See the ARRA period evaluation report, Section 4.4, Tonn et al. (2011).

${ }^{18}$ As of this writing, the identities of the other two agencies are uncertain because of conflicting information in programmatic records.
} 
Version (EZ) was also developed that required only about a dozen data items per home. The following table provides the guidelines used for how many short and EZ versions were required from the agencies.

\begin{tabular}{|l|l|l|}
\hline Survey & Housing type & Sampling approach \\
\hline DF2-EZ & $\begin{array}{l}\text { Single family homes and multifamily } \\
\text { apartments if the whole MF building was } \\
\text { not treated (IUs). }\end{array}$ & $\begin{array}{l}50 \% \text { of sampled SF homes and IUs will get } \\
\text { the DF2-EZ. }\end{array}$ \\
\hline DF2-Short & $\begin{array}{l}\text { Single family homes and multifamily } \\
\text { apartments if the whole MF building was } \\
\text { not treated (IUs). }\end{array}$ & $\begin{array}{l}\text { 50\% of sampled SF homes and IUs will get } \\
\text { the DF2-Short. }\end{array}$ \\
\hline DF3-Unit & $\begin{array}{l}\text { Multifamily apartments in buildings that } \\
\text { got "whole building weatherization" - } \\
\text { 60+\% of units wxd, building shell } \\
\text { measures such as attic insulation and air } \\
\text { sealing, central heating \& cooling } \\
\text { upgrades }\end{array}$ & $\begin{array}{l}\text { 100\% of the MF units sampled for PY 2010. } \\
\text { There may be multiple DF3-Unit surveys per } \\
\text { MF building, depending on how many units } \\
\text { were in the DF4 sample. }\end{array}$ \\
\hline $\begin{array}{l}\text { DF3- } \\
\text { Building }\end{array}$ & buildifing weatherization" & $\begin{array}{l}100 \% \text { of the MF buildings sampled for PY } \\
2010 . \text { There will be only one DF3-Building } \\
\text { survey per MF building. }\end{array}$ \\
\hline $\begin{array}{l}\text { SERC } \\
\text { Addendum }\end{array}$ & All & $\begin{array}{l}100 \% \text { of SERC units sampled for DF4 will } \\
\text { also be sampled for DF2/3; all SERC units } \\
\text { will get the Short Form. }\end{array}$ \\
\hline
\end{tabular}

\section{A.3 SURVEY IMPLEMENTATION DETAILS}

The evaluation team used a case manager approach to collect data from grantees and subgrantees. ${ }^{19} \mathrm{~A}$ team of five case managers and two outreach coordinators managed evaluation-related communications and data requests for grantees and subgrantees. Each case manager was assigned a portfolio of states and served as the designated point of contact for the grantee and subgrantees in the state. The case managers worked with their assigned grantees and subgrantees to facilitate and overcome barriers to their participation in the evaluation. Data were collected during CYs 2011 and 2012.

The evaluation team made surveys available in multiple modes to allow flexibility for respondents. All surveys except DF4 were available in a secure online site. ${ }^{20}$ Survey instruments were also made available in Microsoft Word or PDF format. Survey responses were accepted via email, mail, fax and over the phone. The DF4 survey for sampled subgrantees was administered in Microsoft Excel, with files transferred over a secure file-sharing website to protect personal information about WAP participants.

In addition, to alleviate some of the response burden for sampled subgrantees, the team partially precompleted the data forms that requested unit-level data (DF4 and DF2/3) wherever this was feasible using information from state-level databases. In all, the team migrated some data for sampled subgrantees in approximately 40 states. $^{21}$

Overall participation rates ranged from $97 \%$ the grantee survey S1, to $92 \%$ for the subgrantee survey S2, to $84 \%$ for DF2/3. Data were deemed uncollectable in cases where a subgrantee closed down, or when weatherization records were destroyed for some reason. See Table A.1 for a complete accounting. Tables

\footnotetext{
${ }^{19}$ This task was primarily the responsibility of the Energy Center of Wisconsin.

${ }^{20}$ This system was developed and administered by the Dieringer Research Group, Inc.

${ }^{21}$ APPRISE, Inc. was primarily responsible for data base migration.
} 
A.2 and A.3 report the number of housing and building data forms and utility-related data forms, respectively, collected by housing type and climate zone.

Table A.1: Sample Sizes and Response Rates

\begin{tabular}{|l|c|c|c|c|c|c|}
\hline & S1 & S2 & S3 & DF2/3 & DF4a & DF4b \\
\hline & Grantees & Subgrantees & Subgrantees & Subgrantees & Subgrantees & Subgrantees \\
\hline Goal & 58 & 934 & 451 & 451 & 451 & 451 \\
\hline Provided Data & 56 & 861 & 380 & 379 & 433 & 398 \\
\hline $\begin{array}{l}\text { Did Not } \\
\text { Respond }\end{array}$ & 2 & 55 & 64 & 64 & 10 & 45 \\
\hline Uncollectable & & 18 & 7 & 8 & 8 & 8 \\
\hline Response Rate & $97 \%$ & $92 \%$ & $84 \%$ & $84 \%$ & $96 \%$ & $88 \%$ \\
\hline
\end{tabular}

Table A.2 Housing and Building Data Forms Collected by House Type and Climate Zone

\begin{tabular}{|l|c|c|c|c|c|c|}
\hline & Very Cold & Cold & Moderate & Hot-humid & Hot-Dry & Total \\
\hline Single Family & 1856 & 3265 & 2075 & 1509 & 842 & 9547 \\
\hline Mobile Home & 506 & 609 & 574 & 464 & 225 & 2378 \\
\hline $\begin{array}{l}\text { Small } \\
\text { Multifamily }\end{array}$ & 234 & 639 & 111 & 73 & 130 & 1187 \\
\hline $\begin{array}{l}\text { Large } \\
\text { Multifamily }\end{array}$ & 607 & 1142 & 269 & 255 & 427 & 2700 \\
\hline Total & 3203 & 5655 & 3029 & 2301 & 1624 & 15812 \\
\hline
\end{tabular}

Table A.3 Utility-Related Data Forms Collected by House Type and Climate Zone

\begin{tabular}{|l|c|c|c|c|c|c|}
\hline & Very Cold & Cold & Moderate & Hot-humid & Hot-Dry & Total \\
\hline Single Family & 4090 & 7771 & 5069 & 3785 & 1869 & 22584 \\
\hline Mobile Home & 1038 & 1376 & 1344 & 1011 & 481 & 5250 \\
\hline $\begin{array}{l}\text { Small } \\
\text { Multifamily }\end{array}$ & 362 & 1034 & 221 & 161 & 318 & 2096 \\
\hline $\begin{array}{l}\text { Large } \\
\text { Multifamily }\end{array}$ & 940 & 2068 & 490 & 689 & 913 & 5100 \\
\hline Total & 6430 & 12249 & 7124 & 5646 & 3581 & 35030 \\
\hline
\end{tabular}

\section{A.4 DATA LIMITATIONS}

The data presented in this report are based almost exclusively on self-reports by grantees and subgrantees. While one can argue that respondents answered the questions in good faith, several factors impinge on the reliability and validity of the data we received. These factors include:

- Loss of institutional memory: Several respondents indicated that no one currently associated with their weatherization program was part of the organization during the program year addressed by this study.

- Inconsistent interpretation of question meaning: Some questions could be interpreted in multiple ways. While respondents were provided mouse-over guidance for some of the questions and clarified questions whenever asked, it is suspected that respondents may have interpreted some questions in different ways than intended without seeking clarification from the evaluation team.

- Recordkeeping: Some respondents keep records - especially financial records — in ways that do not lend themselves to answering specific questions in S1 and S2. In particular, the evaluation team heard from financial staff that they often do not track data in a way that maps easily to the financial matrices we included in two of the surveys. 
Two areas of particular challenge included financial data and unit counts. The financial data received generally matched what we would expect based on other published data, such as the National Association of State Community Service Providers (NASCSP) annual funding survey and data contained in DOE's Performance and Accountability for Grants in Energy (PAGE) database. However, there were inconsistencies in detailed numbers - both within responses from individual grantees or subgrantees and across respondents (grantee reports compared to the sum of subgrantee reports) - and some inconsistencies between aggregate amounts reported to the evaluation team and published funding reports available elsewhere.

The evaluation team followed up with selected grantees to understand the reasons for these apparent discrepancies and to correct obvious reporting errors. These follow-ups suggest that discrepancies among reported financial values were due to multiple factors, including:

- Adjustments to funding distribution and timing of expenditures after states submitted data to the NASCSP funding survey (one of the external data sources we used as a cross-check).

- Inconsistencies in whether funds related to weatherization, such as emergency furnace repair and replacement, were included as weatherization funding.

- Inconsistencies in whether funds coordinated by a grantee but disseminated directly from utilities to subgrantees are counted in state totals.

- Errors in funding amounts reported.

- Uses of funds in ways that do not have a clear home in the reporting structure provided in the surveys.

- Uncertainty by some subgrantees about the mix of funding sources that make up the allocations they receive from their grantee.

Obvious errors were corrected at the direction of grantees, some subgrantee reports were replaced with grantee-provided values, and funding allocations were used in place of missing values for non-responding subgrantees. Nevertheless, reconciling all differences would have gone beyond the scope of our effort and respondents' abilities to answer questions. As a result, readers should keep in mind that financial data reported here may not match other data sources.

Unless otherwise noted, this report presents the funding amounts reported to us by grantees and subgrantees. A few aggregate values were drawn from other sources, such as initial DOE allocations, in order to anchor our discussion of the overall program size to official funding amounts. In those cases, the external source of those data is identified.

Similar apparent discrepancies were found with reported numbers of housing units weatherized under the DOE program. Depending on their funding sources, local agencies can weatherize homes as part of the national WAP program or outside the confines of the program. The evaluation team sought to obtain unit counts by housing type for both DOE and non-DOE projects.

For some grantees and subgrantees, the evaluation team obtained different unit counts for PY 10 from PAGE, state-maintained databases of weatherization projects, and completed units reported by subgrantees on two different instruments. It appears that there is some ambiguity about which projects should be reported as DOE units and differences in how grantees allocate total units to the WAP program. Furthermore, subgrantees do not consistently know which, or how many, of their projects the grantee reported as DOE units to the department. 
As with financial data, unless otherwise noted, the results presented in this report draw from the responses we received from grantees and subgrantees plus whatever data we were able to extract from statewide databases provided to us by some grantees. These data may not match official department production numbers.

A few aggregate values were drawn from other sources, such as official DOE totals from PAGE, in order to anchor our discussion to official measures of overall program activity. In those cases, the external sources of those data are identified. 